\title{
Air temperature variability over three glaciers in the Ortles-Cevedale (Italian Alps): effects of glacier fragmentation, comparison of calculation methods, and impacts on mass balance modeling
}

\author{
L. Carturan ${ }^{1}$, F. Cazorzi ${ }^{2}$, F. De Blasi ${ }^{1}$, and G. Dalla Fontana ${ }^{1}$ \\ ${ }^{1}$ Department of Land, Environment, Agriculture and Forestry, University of Padova, Viale dell'Università 16, 35020 Legnaro, \\ Padova, Italy \\ ${ }^{2}$ Department of Agriculture and Environmental Sciences, University of Udine, via delle Scienze 208, 33100, Udine, Italy \\ Correspondence to: L. Carturan (luca.carturan@unipd.it)
}

Received: 20 November 2014 - Published in The Cryosphere Discuss.: 15 December 2014

Revised: 22 April 2015 - Accepted: 23 April 2015 - Published: 27 May 2015

\begin{abstract}
Glacier mass balance models rely on accurate spatial calculation of input data, in particular air temperature. Lower temperatures (the so-called glacier cooling effect) and lower temperature variability (the so-called glacier damping effect) generally occur over glaciers compared to ambient conditions. These effects, which depend on the geometric characteristics of glaciers and display a high spatial and temporal variability, have been mostly investigated on medium to large glaciers so far, while observations on smaller ice bodies $\left(<0.5 \mathrm{~km}^{2}\right)$ are scarce. Using a data set from eight on-glacier and four off-glacier weather stations, collected in the summers of 2010 and 2011, we analyzed the air temperature variability and wind regime over three different glaciers in the Ortles-Cevedale. The magnitude of the cooling effect and the occurrence of katabatic boundary layer (KBL) processes showed remarkable differences among the three ice bodies, suggesting the likely existence of important reinforcing mechanisms during glacier decay and fragmentation. The methods proposed by Greuell and Böhm (1998) and Shea and Moore (2010) for calculating on-glacier temperature from off-glacier data did not fully reproduce our observations. Among them, the more physically based procedure of Greuell and Böhm (1998) provided the best overall results where the KBL prevails, but it was not effective elsewhere (i.e., on smaller ice bodies and close to the glacier margins). The accuracy of air temperature estimations strongly impacted the results from a mass balance model which was applied to the three investigated glaciers. Most importantly,
\end{abstract}

even small temperature deviations caused distortions in parameter calibration, thus compromising the model generalizability.

\section{Introduction and background}

Air temperature exerts a crucial control on the energy and mass exchanges occurring at the glacier surface. It regulates the accumulation processes via the snowfall elevation limit and the snowpack metamorphism (which affect redistribution phenomena) and regulates the ablation processes via turbulent fluxes and long-wave radiation. It is also closely related to important feedbacks such as albedo, the mass balanceelevation feedback, and the glacier cooling effect, which changes as glaciers adjust their size in response to climatic fluctuations (Khodakov, 1975; Klok and Oerlemans, 2004; Paul et al., 2005; Raymond and Neumann, 2005; Haeberli et al., 2007; Fischer, 2010; Paul, 2010; Carturan et al., 2013).

Distributed models of different complexity have been proposed for calculating the mass balance of glaciers under different climatic scenarios at a variety of spatial scales and with different purposes. The current concern about sea level rise and future availability of water resources stored in glaciers, under projected global warming scenarios, has led to increased efforts to develop models able to account for (i) direct effects of climate change and (ii) reinforcing 
mechanisms which control glacier decay (Hock, 2005; Barry, 2006).

These models rely on accurate spatial calculation of input data, in particular air temperature, which affects not only their final performance but also the calibration of parameters and model generalizability. Indeed, wrong temperature estimates lead to wrong calibration and/or distortion of parameters, possibly hampering the applicability of models to ungauged catchments, despite the good knowledge achieved for individual processes (Savenije, 2001; Sivapalan, 2006).

Charbonneau et al. (1981), for example, highlighted that issues in extrapolating meteorological input data are much more crucial than the possible choice between different approaches for modeling snow yields from a well-equipped catchment in the French Alps. Similarly, intercomparison projects of runoff models by the World Meteorological Organization (e.g., WMO, 1986) revealed that simple models provided results comparable to more sophisticated models, given the difficulties of assigning proper model parameters and meteorological input data to each catchment element. Machguth et al. (2008), analyzing model uncertainty with Monte Carlo simulations at one point on the tongue of Morteratsch Glacier in Switzerland, concluded that the output of well-calibrated models, when applied to extrapolate in time and space, is subject to considerable uncertainties due to the quality of input data. According to Carturan et al. (2012a), who compared three melt algorithms in a 6-year application of an enhanced temperature-index model over two Italian glaciers, uncertainties in extrapolating temperature measurements from off-site data partly mask the peculiar behavior of each algorithm and do not allow definitive conclusions to be drawn.

Two main issues affect the correct estimation of air temperature distribution over glacial surfaces: (i) the absence of on-site weather stations in most operational model applications and (ii) the development of a katabatic boundary layer (KBL) over the typically inclined glacier surfaces (van den Broeke, 1997). Several experiments with automatic weather stations (AWSs) deployed over glaciers demonstrated that general assumptions in extrapolating air temperature, based on the application of fixed lapse rates which account for the linear dependency of ambient (i.e., off-glacier) temperature on altitude, have serious limitations (e.g., Greuell et al., 1997; Strasser et al., 2004; Petersen and Pellicciotti, 2011).

In particular, these assumptions do not apply when katabatic flows and the KBL form, that is, during the ablation season on melting mid-latitude glacial surfaces, when the ambient temperature is higher than the surface temperature, which cannot exceed $0^{\circ} \mathrm{C}$. Katabatic winds are gravity winds originated by the cooling of the near-surface air layers, resulting in density gradients that force a downward movement of the air under the effect of gravity. The two main processes affecting the temperature of the air during this downslope movement are the cooling due to the exchange of sensible heat and the adiabatic heating. The interplay of these pro- cesses has a twofold effect, consisting of lower on-glacier temperatures (the so-called glacier cooling effect) and lower temperature variability (the so-called glacier damping effect, also referred to as reduced climate sensitivity) compared to ambient conditions (Braithwaite, 1980; Greuell and Böhm, 1998; Braithwaite et al., 2002; Gardner et al., 2009). As a result, on-glacier lapse rates generally differ from average environmental lapse rates (i.e., $-0.0065^{\circ} \mathrm{Cm}^{-1}$ ). Cooling and damping effects are not homogeneous over glacial surfaces and mainly depend on the size and geometric characteristics, in particular the slope, of single glaciers and on the specific position along the glacier. Generally, they are directly related to the size of glaciers and the fetch distance along the flow line and inversely related to the slope of glaciers. The latter controls the prevalence of the cooling due to turbulent exchanges over the adiabatic heating of air forced to move downward by katabatic winds.

Few methods have been proposed in the literature to model these processes, mainly due to the scarcity of glaciers instrumented for distributed measurements of air temperature. Among the first authors who measured the glacier cooling effect, defined as the temperature difference between an onglacier and an off-glacier site with the same altitude, were Schytt (1955) and Eriksson (1958), who detected temperature depressions ranging from 1.1 to $2.2^{\circ} \mathrm{C}$ on Storglaciären (Sweden) and $3-4{ }^{\circ} \mathrm{C}$ on Skagast $\varnothing \mathrm{l}$ Glacier (Norway), respectively. Havens (1964) measured an average cooling effect ranging from 1.5 to $2.7^{\circ} \mathrm{C}$ at a weather station located $1 \mathrm{~km}$ up-glacier from the terminus of White Glacier (Canada), recognizing maximum values during warm and sunny weather and minimum values during overcast and unsettled weather.

To our knowledge, the first attempt to parameterize the mean summer cooling effect at the firn line altitude was made by Khodakov (1975), who proposed a relationship with glacier length based on temperature data obtained from mountain glaciers and ice sheets. Analyzing direct observations from glaciers in Caucasus, Pamir, Scandinavia, Tian Shan, and Altay, Davidovich and Ananicheva (1996) provided a simple relationship for calculating the mean summer temperature at the equilibrium line altitude (ELA) in function of the mean off-glacier summer temperature at the same altitude. The same authors suggested that the cooling effect is maximal at the ELA and decreases towards both the terminus and up-glacier.

The first comprehensive glacial-meteorological experiment providing distributed temperature measurements was carried out in summer 1994 on Pasterze Glacier, Austria, and comprised five automatic weather stations placed along a flow line. From this experiment, Greuell and Böhm (1998) developed a thermodynamic model for calculating air temperature in function of slope and distance along the flow line, accounting for sensible heat exchanges and adiabatic heating. Braithwaite et al. (2002) used an empirical approach and a formulation derived from data gathered in two Cana- 
dian Arctic glaciers (Sverdrup and White), similar to that proposed by Davidovich and Ananicheva (1996) but applied to monthly temperatures. Shea and Moore (2010) suggested empirical relationships based on piecewise linear regressions of on-glacier vs. ambient temperatures collected in British Columbia (Canada) between 2006 and 2008 for calculating (i) the threshold temperature triggering KBL development and (ii) the glacier damping effect as a function of elevation and flow path length (i.e., the "average flow distance to a given point starting from an upslope limit or ridge").

At present these methods have rarely been used by other authors, and they have not been compared using independent test sites. Petersen et al. (2013) tested the Greuell and Böhm (1998) model using a data set of air temperature measurements from Haut Glacier d'Arolla, Switzerland, concluding that results of spatial extrapolations along the glacier are only a little better than using a constant linear lapse rate calculated between on-glacier data points, attributing this result to the spatial variability of the thickness of the glacier boundary layer.

The transferability of the proposed methods remains to be tested. In addition, it should be noted that many of them have been developed using temperature data collected from medium (from 0.5 to $10 \mathrm{~km}^{2}$ ) to large (larger than $10 \mathrm{~km}^{2}$ ) glaciers. As the glacier cooling effect and the damping effect depend on the size of glaciers, it is opportune to investigate the thermal effects of ice bodies smaller than $0.5 \mathrm{~km}^{2}$, which are widespread and increasing in number in mid-latitude mountain regions as a result of glacier shrinking and fragmentation.

In this work we present the results of a glacialmeteorological experiment, carried out in summer 2010 and 2011, deploying several automatic weather stations over three neighboring glaciers in the Ortles-Cevedale mountain group (Italian Alps). The study was focused on the variability of air temperature over the three glaciers which differ in size, geometric characteristics, and reaction to climatic changes (Carturan et al., 2014). In this paper, we analyze the temporal and spatial behavior of air temperature and glacier cooling effect in the study area, testing existing methods for calculating on-glacier temperatures from off-site data and evaluating their impact in mass balance simulations using a distributed enhanced temperature-index model.

\section{Study area}

The investigated glaciers are located in the Alta Val de la Mare (AVDM), eastern Italian Alps (Fig. 1). This $36 \mathrm{~km}^{2}$ experimental watershed is the subject of detailed studies concerning the impacts of climate change on the cryosphere and hydrology. The area has previously been selected for studying the behavior of meteorological variables at high altitude (Carturan et al., 2012b) and for developing an enhanced temperature-index glacier mass balance model
(Carturan et al., 2012a). The highest summit is Mount Cevedale (3769 ma.s.l.), while the basin outlet is located at $1950 \mathrm{~m}$ a.s.l. The catchment lies in the southern part of the Ortles-Cevedale massif, the largest glacierized mountain group in the Italian Alps. The Careser Diga weather station ( $2607 \mathrm{~m}$ a.s.l.) has been operating since the 1930s, recording daily $2 \mathrm{~m}$ air temperature, precipitation, snow depth, and fresh-snow height. In the 1990s, an automatic weather station replaced the old manual instruments. At this site, the mean 1979-2009 annual precipitation (corrected for gauge errors) was $1233 \mathrm{~mm}$ and the mean annual air temperature in the same period was $-0.5^{\circ} \mathrm{C}$.

The investigated glaciers are very different. Careser Glacier (2870-3279 ma.s.l.) is flat and mainly exposed to the south. In 2005 it spread in two parts: Careser Orientale $\left(2.13 \mathrm{~km}^{2}\right.$ in 2006) and Careser Occidentale $\left(0.27 \mathrm{~km}^{2}\right.$ in 2006). La Mare Glacier (2650-3769 ma.s.1., $3.79 \mathrm{~km}^{2}$ in 2006) faces to the east and is steeper. On all glaciers, topographic shading is of minor importance. The Careser glaciers have no accumulation area and exhibit down-wasting and fragmentation in smaller units (Carturan et al., 2013), while La Mare Glacier still has an accumulation area and shows "active" retreat towards higher altitudes (Zanon, 1982; Small, 1995; Carturan et al., 2009, 2014). Long-term monitoring programs started in 1967 on Careser and in 2003 on La Mare. In the last 10 years, the glaciers have been the subject of investigations on snow accumulation, snow and ice ablation, point energy balance, and runoff generation (Carturan, 2010).

\section{Methods}

\subsection{Experimental setup}

An AWS has been operating since July 2007 on the ablation area of La Mare Glacier (2973 ma.s.1.), measuring air temperature and relative humidity, wind speed and direction, incoming and outgoing shortwave and long-wave radiation, and snow depth. The thermo-hygrometric probe is housed in a ventilated radiation shield. Data are sampled every $60 \mathrm{~s}$, with 15 min means stored in a Campbell Scientific CR1000 data logger; the AWS is powered by a $25 \mathrm{~W}$ solar panel. Data were periodically downloaded with a portable laptop until July 2011. Since August 2011, a satellite modem has automatically transmitted data at 3-day intervals (Abbate et al., 2013).

On 3 July 2010 three Vantage Pro Plus (VPP) weather stations, manufactured by Davis Instruments, were placed along a longitudinal profile on La Mare Glacier at elevations ranging from $2709 \mathrm{~m}$, close to the terminus, to $3438 \mathrm{~m}$, near to the upper divide. Davis VPP stations are low-cost, commercial weather stations, characterized by a compact design and low weight, that can be moved rather easily along glaciers by few persons. Their thermo-hygrometric probe is shielded 


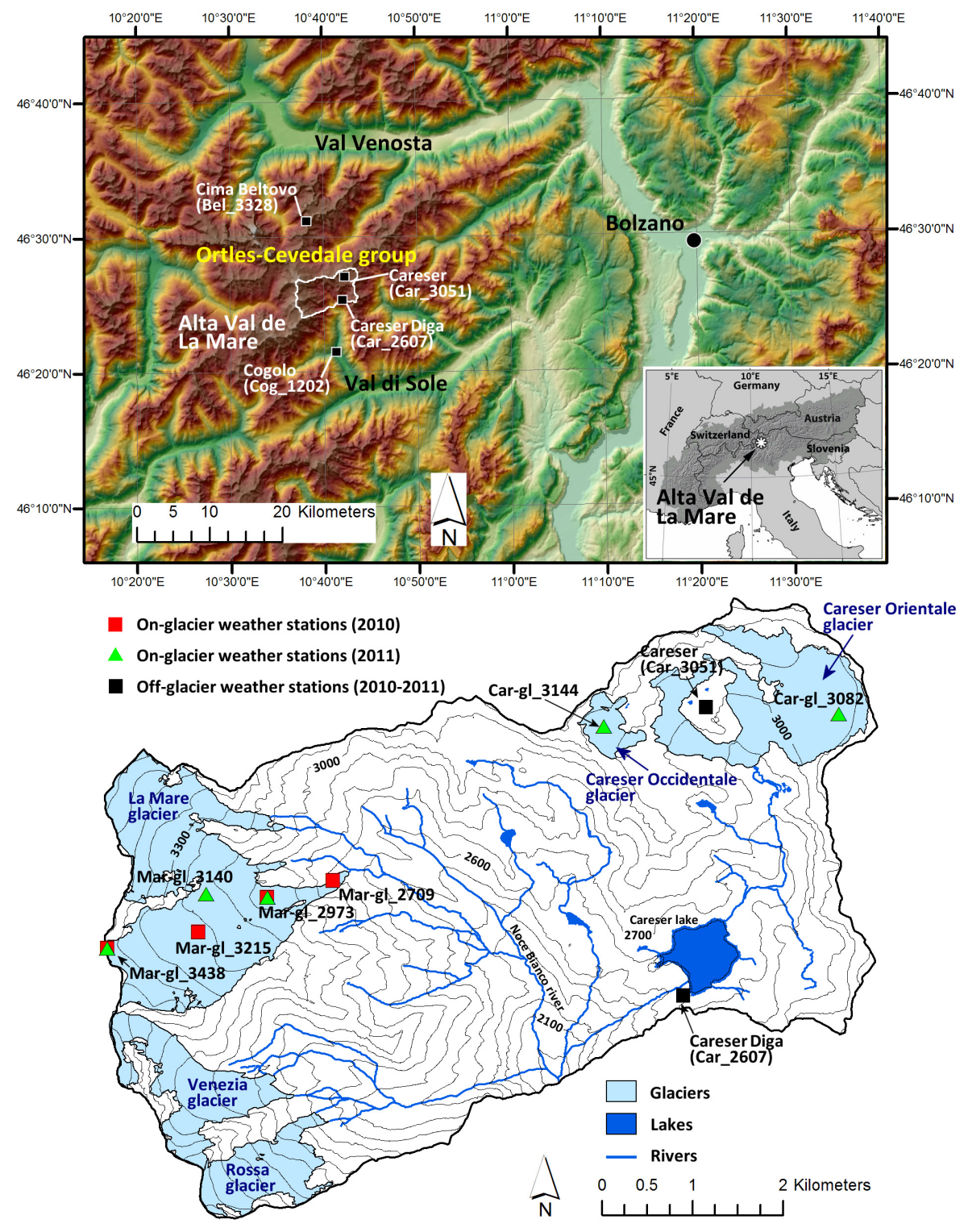

Figure 1. Geographic setting of Alta Val de La Mare and location of the automatic weather stations.

by a ventilated screen, which is important for air temperature measurements in high-radiation and/or low-wind-speed conditions on glaciers (Georges and Kaser, 2002). Hourly mean data are stored in a Davis data logger. During the experiment, the data were downloaded with a portable laptop every 2 weeks. The three VPP stations were removed on 23 September 2010.

On 7 July 2011 four VPP stations were deployed, two on Careser Glacier and two on La Mare Glacier. One weather station was re-positioned at $3438 \mathrm{~m}$ on La Mare Glacier because instrumentation failure occurred at that place in 2010 due to lightning damage. The other three weather stations were placed in areas where systematic errors in mass balance simulations were recognized by Carturan et al. (2012a), who applied a mass balance model using the standard environmental lapse rate for extrapolating air temperature from an off-glacier weather station, as commonly used in most model applications where on-glacier data are not available. The four VPP stations were removed on 12 September 2011.

Table 1 reports the configuration of the weather stations operated on Careser and La Mare glaciers, locations of which are shown in Fig. 1. Four off-glacier weather stations (Table 1) were also used in this study for the calculation of the glacier cooling effect in comparison to ambient temperature and for testing two methods of calculation of on-glacier temperatures from off-site data. Two of them are part of the regional weather station networks (Bel_3328, at Cima Beltovo, 3328 m a.s.l.; Cog_1202, at Cogolo Pont, 
Table 1. Location, flow path length (FPL), period of observation, and used variables for glacier and ambient weather stations*. The periods with common records are 3 July-23 September 2010 and 7 July-12 September 2011.

\begin{tabular}{|c|c|c|c|c|c|c|c|}
\hline \multirow[t]{2}{*}{ Weather station } & \multirow{2}{*}{$\begin{array}{c}\text { Easting } \\
\text { (m) }\end{array}$} & \multirow{2}{*}{$\begin{array}{l}\text { Northing } \\
\text { (m) }\end{array}$} & \multirow{2}{*}{$\begin{array}{c}\text { Elevation } \\
\text { (ma.s.1.) }\end{array}$} & \multirow{2}{*}{$\begin{array}{l}\text { FPL } \\
(\mathrm{m})\end{array}$} & \multicolumn{2}{|c|}{ Period of observation } & \multirow[t]{2}{*}{ Used variables } \\
\hline & & & & & $\begin{array}{c}\text { Summer } \\
2010\end{array}$ & $\begin{array}{c}\text { Summer } \\
2011\end{array}$ & \\
\hline \multicolumn{8}{|l|}{ La Mare Glacier } \\
\hline Mar-gl_2709 & 626692 & 5143668 & 2709 & 2896 & $\mathrm{x}$ & & $T, W$ \\
\hline Mar-gl_2973 & 625960 & 5143483 & 2973 & 2132 & $\mathrm{x}$ & $\mathrm{x}$ & $T, W$ \\
\hline Mar-gl_3215 & 625205 & 5143101 & 3215 & 1278 & $\mathrm{x}$ & & $T, W$ \\
\hline Mar-gl_3140 & 625290 & 5143523 & 3140 & 805 & & $\mathrm{x}$ & $T, W$ \\
\hline Mar-gl_3438 & 624199 & 5142924 & 3438 & 40 & damaged & $\mathrm{x}$ & $T, W$ \\
\hline \multicolumn{8}{|l|}{ Careser Glacier } \\
\hline Car-gl_3082 & 632283 & 5145512 & 3082 & 313 & & $\mathrm{x}$ & $T, W$ \\
\hline Car-gl_3144 & 629690 & 5145375 & 3144 & 354 & & $\mathrm{x}$ & $T, W$ \\
\hline \multicolumn{8}{|c|}{ Ambient weather stations } \\
\hline Cog_1202 & 629915 & 5135988 & 1202 & $\backslash$ & $\mathrm{x}$ & $\mathrm{x}$ & $T$ \\
\hline Car_2607 & 630570 & 5142410 & 2607 & 1 & $\mathrm{x}$ & $\mathrm{x}$ & $T, P$ \\
\hline Car_3051 & 630799 & 5145553 & 3051 & 1 & $\mathrm{x}$ & $\mathrm{x}$ & $T$ \\
\hline Bel_3328 & 624957 & 5151212 & 3328 & 1 & $\mathrm{x}$ & $\mathrm{x}$ & $T$ \\
\hline
\end{tabular}

* $T$ : air temperature; $W$ : wind speed and direction; $P$ : precipitation. On-glacier sites are in bold type.

The " $\mathrm{x}$ " indicates the periods of observations for each station.

$1202 \mathrm{~m}$ a.s.1., Fig. 1). The other two weather stations consist of HOBO Pro data loggers (Onset Computer Corporation) installed at Careser Diga (Car_2607, at $2607 \mathrm{~m}$ a.s.1.) and close to Careser Glacier (Car_3051, at $3051 \mathrm{~m}$ a.s.1.). All these stations are far enough from the thermal influence of glaciers (minimum distance of $300 \mathrm{~m}$ from Car_3051 to the margin of Careser Glacier) and equipped with temperature probes housed in naturally ventilated radiation shields. Possible issues related to the use of different types of temperature sensors and radiation shields are addressed in the following section.

\subsection{Data processing and accuracy assessment}

For our analyses, hourly means were calculated from subhourly meteorological data. After being synchronized with local solar time, the data were checked for possible gaps, outliers, and inhomogeneities. The major gap concerned a few days in summer 2011 in the precipitation data at Careser Diga, which was filled using the manual observations recorded by the personnel of the local hydropower company. Other gaps of 1-2 h occurred during the maintenance of weather stations and were filled by linear interpolation.

The spatial density and type of weather stations used in this study were decided based on (i) the pre-existing network of regional AWSs and (ii) the logistic constraints affecting the access to the glaciers and limiting the number of research-grade AWSs which could be deployed. These limi- tations are common in mountain regions and imposed comparable or even lower densities of AWSs, as well as the use of different types of sensors with different radiation shields, in most similar studies on glaciers (e.g., Shea and Moore, 2010; Petersen and Pellicciotti, 2011; Petersen et al., 2013).

Intercomparison tests have been carried out in order to assess the impact of using different sensors and radiation shields for this study. The four VPP weather stations were run for some days within a $10 \mathrm{~m}$ radius, both before and after the glacial-meteorological experiment, confirming the almost identical readings of air temperature, wind speed, and wind direction. Mean differences in air temperature data during the tests were lower than $0.20^{\circ} \mathrm{C}$ (maximum $\mathrm{STD}=0.16^{\circ} \mathrm{C}$ ). For comparison purposes, one VPP station was run close to the AWS of La Mare Glacier in summer 2009, revealing mean differences in air temperature readings of $0.10^{\circ} \mathrm{C}\left(\mathrm{STD}=0.12^{\circ} \mathrm{C}\right)$. A further comparison was carried out in the summers of 2007 and 2008, running a VPP station close to the HOBO Pro data logger and close to a temperature sensor of the regional weather service installed at Careser Diga. These two instruments, which have natural ventilation systems, showed mean differences of $0.10^{\circ} \mathrm{C}$ $\left(\mathrm{STD}=0.40^{\circ} \mathrm{C}\right)$ and $0.23^{\circ} \mathrm{C}\left(\mathrm{STD}=0.66^{\circ} \mathrm{C}\right)$, respectively, compared to the aspirated VPP station. Based on these results, no corrections were applied to the measured air temperatures. 


\subsection{Analysis of field data}

The meteorological data collected by the weather stations were firstly analyzed by calculating descriptive statistics for each of the two summers 2010 and 2011 and focusing on vertical lapse rates. Afterwards, the data were analyzed at hourly resolution focusing on the calculation of ambient (i.e., off-glacier) temperature, which is crucial for estimating on-glacier near-surface temperatures and is required by all methods proposed in the literature for this purpose. Moreover, the correct estimation of the ambient temperature is an essential prerequisite for quantifying the site-specific cooling effect on glaciers, which is defined as "the difference between screen-level temperatures over glaciers compared to equivalent-altitude temperatures in the free atmosphere" (Braithwaite, 1980). Different combinations of lapse rates (i.e., fixed standard or hourly variable obtained by linear regression of temperature vs. elevation) and subsets of weather stations were tested (see details in Sect. 4.2).

The spatial and temporal variability of the cooling effect were then investigated, plotting the average diurnal cycle of the cooling effect vs. average cycles of wind speed and direction and drawing charts of the daily average cooling effect vs. daily temperature and precipitation recorded at Careser Diga, in order to assess the role of different weather types in the glacial temperature regimes.

\subsection{Calculation of on-glacier temperature from off-site data}

The measured on-glacier temperatures served for testing the procedures suggested by Shea and Moore (2010) and Greuell and Böhm (1998) (from now on "S\&M" and "G\&B", respectively) for calculating the air temperature distribution over glacierized surfaces. The empirical methods by Khodakov (1975), Davidovich and Ananicheva (1996), and Braithwaite et al. (2002) were not tested because they are more empiri$\mathrm{cal}$, the coefficients were calculated in very different environments, and they do not take into account the temporal variability of the cooling effect.

S\&M suggested the use of a piecewise regression model:

$T_{\mathrm{g}}(x, t)= \begin{cases}T_{1}+k_{2}\left(T_{\mathrm{a}}-T^{*}\right), & T_{\mathrm{a}} \geq T^{*} \\ T_{1}-k_{1}\left(T^{*}-T_{\mathrm{a}}\right), & T_{\mathrm{a}}<T^{*},\end{cases}$

where $T_{\mathrm{g}}(x, t)\left({ }^{\circ} \mathrm{C}\right)$ is the on-glacier temperature for site $x$ at time $t, T^{*}\left({ }^{\circ} \mathrm{C}\right)$ represents a threshold ambient temperature for KBL effects on $T_{\mathrm{g}}, T_{1}\left({ }^{\circ} \mathrm{C}\right)$ is the corresponding on-glacier threshold temperature, and $k_{2}\left(k_{1}\right)$ is the so-called sensitivity of on-glacier temperature to ambient temperature $\left(T_{\mathrm{a}},{ }^{\circ} \mathrm{C}\right.$ ) changes when $T_{\mathrm{a}}$ is above (below) $T^{*}$. Empirical transfer functions were obtained by $\mathrm{S} \& \mathrm{M}$, relating the fitted coefficients $\left(T^{*}, k_{1}\right.$, and $\left.k_{2}\right)$ for each weather station used in their work to topographic attributes extracted from a digital elevation model (DEM):

$T^{*}=\beta_{1}+\beta_{2} Z$,

$k_{1}=\beta_{3} \exp \left(\beta_{4} \mathrm{FPL}\right)$,

$k_{2}=\beta_{5}+\beta_{6} \exp \left(\beta_{7} \mathrm{FPL}\right)$,

where $\beta_{i}$ are the coefficients of the transfer functions, $Z$ (m) is the elevation, and FPL (m) is the flow path length, defined as "the average flow distance to a given point starting from an upslope summit or ridge" (Shea and Moore, 2010). $T_{1}$ is calculated as $T^{*} \cdot k_{1}$.

The G\&B model assumes the presence of a katabatic wind, and therefore it applies when the ambient temperature is higher than the surface temperature. In these conditions the potential temperature $\Theta\left({ }^{\circ} \mathrm{C}\right)$ at the distance $x$ along the flow line ( $x=0$ at the top of the flow line) is calculated as

$$
\Theta(x)=\left(T_{0}-T_{\mathrm{eq}}\right) \exp \left(-\frac{x-x_{0}}{L_{\mathrm{R}}}\right)-b\left(x+x_{0}\right)+T_{\mathrm{eq}},
$$

with

$$
\begin{aligned}
T_{0} & =T_{\mathrm{cs}}-\gamma\left(z_{\mathrm{cs}}-z_{0}\right), \\
T_{\mathrm{eq}} & =b L_{\mathrm{R}}, \\
L_{\mathrm{R}} & =\frac{H \cos (\alpha)}{C_{\mathrm{H}}}, \\
b & =\Gamma_{\mathrm{d}} \tan (\alpha),
\end{aligned}
$$

where $T_{0}\left({ }^{\circ} \mathrm{C}\right)$ is the temperature at $x=0, T_{\mathrm{eq}}\left({ }^{\circ} \mathrm{C}\right)$ is defined as the "equilibrium temperature", $x_{0}$ and $z_{0}(\mathrm{~m})$ are the location and elevation where the air enters the glacier-wind layer, $T_{\mathrm{cs}}\left({ }^{\circ} \mathrm{C}\right)$ and $z_{\mathrm{cs}}(\mathrm{m})$ are the temperature and the elevation at the off-glacier weather station, $\gamma\left({ }^{\circ} \mathrm{Cm}^{-1}\right)$ is the ambient lapse rate, $H(\mathrm{~m})$ is the height of the glacier wind layer, $\alpha$ $\left(^{\circ}\right)$ is the glacier slope, $C_{\mathrm{H}}$ is the bulk transfer coefficient for heat, and $\Gamma_{\mathrm{d}}$ is the dry adiabatic lapse rate $\left(-0.0098^{\circ} \mathrm{Cm}^{-1}\right)$. The potential temperature is converted into temperature by means of

$T(x, z)=\Theta(x)-\Gamma_{\mathrm{d}}[z(x=0)-z(x)]$,

where $z(x)$ is the surface profile of the glacier.

For both methods, the original formulations and parameters were tested unchanged against our experimental data, evaluating also possible modifications as detailed in Sect. 4. The efficiency was evaluated by means of three different statistics: (i) the mean error (ME), (ii) the root mean square error (RMSE), and (iii) the efficiency criterion by Nash and Sutcliffe (N\&S, 1970). The topographic information required to apply these methods was extracted from a $2 \mathrm{~m} \times 2 \mathrm{~m}$ DEM surveyed by LiDAR in late summer of 2006. A map of the FPL was calculated from this DEM, using algorithms developed for drainage area calculations (Fig. 2, Tarboton et al., 1991). 


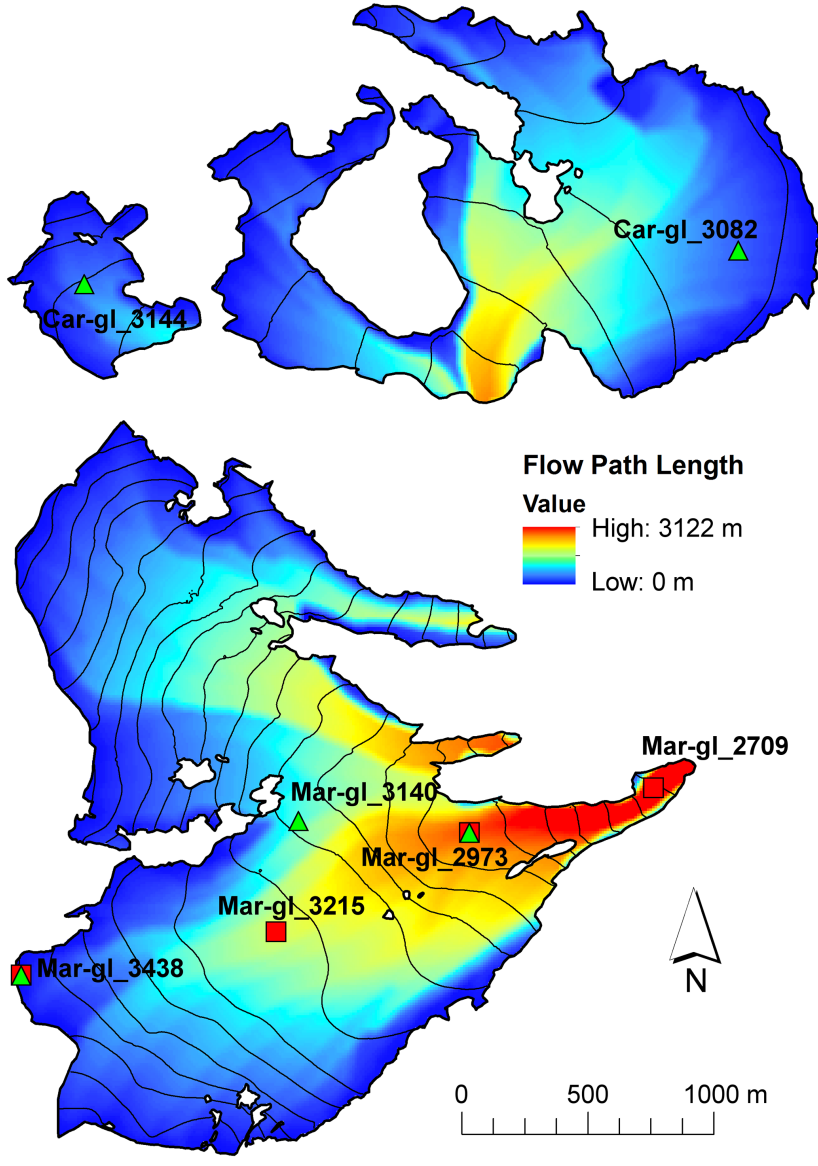

Figure 2. Map of the flow path length calculated for Careser and La Mare glaciers.

\subsection{Mass balance modeling}

The impact that the calculation of on-glacier temperatures according to different methods has on mass balance modeling was assessed using EISModel (Cazorzi and Dalla Fontana, 1996), which was already applied to Careser and La Mare glaciers by Carturan et al. (2012a). EISModel employs an enhanced temperature-index approach for computing melt, using the clear-sky shortwave radiation calculated from the DEM as a distributed morpho-energetic index. The model, which is suitable for applications on glaciers with limited data availability, does not require incoming shortwave radiation measurements, which are less commonly available than air temperature and precipitation. We tested the effect of including daily cloudiness in our mass balance calculations, computing it from incoming shortwave radiation measured at Mar-gl_2973, as detailed in Pellicciotti et al. (2005). As no significant changes were obtained in the efficiency statistics, we assumed that the daily cloudiness could be omitted in mass balance calculations.

Three melt algorithms (multiplicative, additive, and extended) have been implemented and can be used alternatively in EISModel. In the present work we use the additive melt algorithm, which explicitly separates the thermal and radiative components:

$\operatorname{MLT}_{X, t}=\left[\mathrm{TMF} \cdot T_{X, t}\right]+\left[\mathrm{RMF} \cdot \mathrm{CSR}_{X, t}\left(1-\alpha_{X, t}\right)\right]$,

where TMF and RMF are empirical coefficients called the temperature melt factor $\left(\mathrm{mmh}^{-1}{ }^{\circ} \mathrm{C}^{-1}\right)$ and the radiation melt factor $\left(\mathrm{mm} \mathrm{h}^{-1} \mathrm{~W}^{-1} \mathrm{~m}^{2}\right), T_{X, t}\left({ }^{\circ} \mathrm{C}\right)$ is the air temperature at pixel $X$ in hour $t, \operatorname{CSR}_{X, t}\left(\mathrm{Wm}^{-2}\right)$ is the clear sky shortwave radiation, and $\alpha_{X, t}$ is the surface albedo (spatially variable for ice and spatially and temporally variable for snow). For a detailed description of the model, we refer the reader to the work of Carturan et al. (2012a).

The cumulated mass balance measured at ablation stakes drilled in close proximity to the glacial weather stations (AWS and VPP) served for model calibration and validation. We used alternatively each of the two summer seasons of 2010 and 2011 as an independent data set for calibration/validation. Point-based EISModel calculations at the weather stations were run, using four temperature series: (i) measured data, (ii) calculated temperature from Careser Diga via the standard ambient lapse rate $\left(-6.5^{\circ} \mathrm{C} \mathrm{km}^{-1}\right)$, (iii) calculated temperature according to the $\mathrm{S} \& \mathrm{M}$ method, and (iv) calculated temperature according to the $G \& B$ method. Option (ii) is commonly used in the absence of temperature data from glaciers (e.g., Gardner and Sharp, 2009; Michlmayr et al., 2008; Nolin et al., 2010).

\section{Results}

\subsection{Seasonal characteristics of temperature data}

A close dependency on altitude has been detected for mean summer air temperature, both outside the glaciers and, remarkably, over them (Table 2, Fig. 3). Because of thermal inversions occurring at the lowermost weather station (Cog_1202) during the night and early morning, the vertical lapse rate was much steeper above Car_2607 $\left(-8.0^{\circ} \mathrm{Ckm}^{-1}\right.$ in 2010 and $-8.3^{\circ} \mathrm{C} \mathrm{km}^{-1}$ in 2011) than below $\left(-5.3^{\circ} \mathrm{C} \mathrm{km}^{-1}\right.$ in 2010 and $-5.2^{\circ} \mathrm{C} \mathrm{km}^{-1}$ in 2011). At a given altitude, the on-glacier air temperature was systematically lower than ambient temperature, the difference decreasing with altitude. Lapse rates were also lower on the glaciers $\left(-7.2^{\circ} \mathrm{Ckm}^{-1}\right.$ in 2010 and $-6.7^{\circ} \mathrm{Ckm}^{-1}$ in 2011$)$, compared to high-altitude off-glacier weather stations, and close to the standard ambient lapse rate $\left(-6.5^{\circ} \mathrm{C} \mathrm{km}^{-1}\right)$. Much shallower on-glacier lapse rates and fewer dependency of air temperature on elevation were found by earlier works (e.g., Greuell and Böhm, 1998; Strasser et al., 2004; Petersen et al., 2013). As reported in Table 2, the average daily temperature range and the average standard deviation are largest at the valley floor and both decrease with altitude, reaching their minima over the glaciers as previously reported, for example, by Oerlemans (2001). Hourly temperatures among 
Table 2. Descriptive statistics for air temperature data recorded by the weather stations. On-glacier sites are in bold type.

\begin{tabular}{lrrrrr}
\hline $\begin{array}{l}\text { Weather } \\
\text { station }\end{array}$ & Minimum & Maximum & Mean & $\begin{array}{r}\text { Standard } \\
\text { deviation }\end{array}$ & $\begin{array}{r}\text { Mean } \\
\text { daily } \\
\text { range }\end{array}$ \\
\hline Summer 2010 & & & & & \\
\hline Mar-gl_2709 & -1.9 & 14.2 & 5.9 & 3.3 & 2.2 \\
Mar-gl_2973 & -4.4 & 11.6 & 3.8 & 3.1 & 2.5 \\
Mar-gl_3215 & -6.6 & 10.6 & 2.2 & 3.4 & 2.9 \\
Cog_1202 & 2.3 & 29.8 & 14.8 & 5.5 & 10.2 \\
Car_2607 & -2.4 & 18.4 & 7.3 & 4.1 & 4.6 \\
Car_3051 & -5.6 & 14.1 & 3.9 & 4.0 & 2.8 \\
Bel_3328 & -10.5 & 13.9 & 1.5 & 4.5 & 3.6 \\
\hline Summer2011 & & & & & \\
\hline Mar-gl_2973 & -4.8 & 12.0 & 4.3 & 2.7 & 2.6 \\
Mar-gl_3140 & -6.2 & 9.7 & 3.3 & 2.8 & 2.1 \\
Mar-gl_3438 & -7.9 & 9.5 & 1.1 & 3.1 & 3.2 \\
Car-gl_3082 & -6.0 & 10.8 & 3.3 & 2.9 & 2.6 \\
Car-gl_3144 & -6.1 & 10.9 & 3.5 & 3.1 & 2.3 \\
Cog_1202 & 4.0 & 29.8 & 15.4 & 4.9 & 10.5 \\
Car_2607 & -0.9 & 19.5 & 8.1 & 3.6 & 4.9 \\
Car_3051 & -5.3 & 13.7 & 4.6 & 3.5 & 2.8 \\
Bel_3328 & -8.2 & 13.5 & 2.1 & 3.8 & 3.5 \\
\hline
\end{tabular}
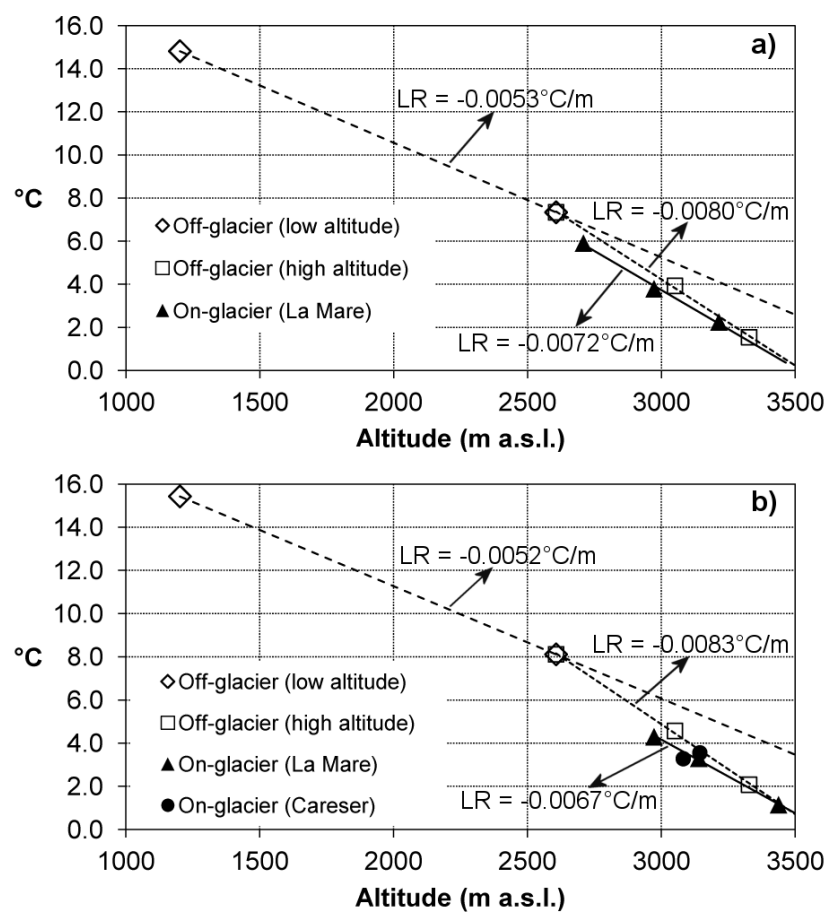

Figure 3. Mean temperature vs. altitude: (a) from 3 July to 23 September, 2010, and (b) from 7 July to 12 September, 2011. Lines indicate linear regressions of temperature vs. altitude for subsets of weather stations. $\mathrm{LR}=$ vertical lapse rates. different weather stations in Val de La Mare were highly correlated $(r>0.9$, significant at the 0.001 level), with the remarkable exception of Cog_1202, at the valley floor, whose correlation with the other weather stations ranged from 0.65 to 0.75 , peaking at 0.84 with Car_2607.

\subsection{Ambient temperature calculation}

For the calculation of ambient temperature at the altitude of glaciers, which is crucial for the quantification of the glacier cooling effect, we tested the following methods: (i) use of a fixed standard ambient lapse rate $\left(-6.5^{\circ} \mathrm{C} \mathrm{km}^{-1}\right)$, (ii) use of a fixed calibrated lapse rate (seasonal mean value), and (iii) use of an hourly variable lapse rate. Methods (ii) and (iii) were implemented using different combinations of off-glacier weather stations, calculating linear regressions of hourly temperature vs. altitude. The methods were tested removing alternatively Car_3051 or Bel_3328 from linear regressions and using them for validation. The results, displayed in Table 3, show that regardless of the method used, the inclusion of the lowermost weather station gives poorer results. At Car_3051, the method (iii) applied to Car_2607 and Bel_3328 works best, indicating that in our case hourly variable lapse rates are the most appropriate solution while interpolating temperatures between two weather stations. Conversely, method (ii) applied to Car_2607 and Car_3051 provides the best results at Bel_3328, which suggests that a fixed calibrated lapse rate should be used while extrapolating above the uppermost station, although uncertainty persists in these cases.

\subsection{The glacier cooling effect}

The cooling effect at each on-glacier weather station was calculated as the difference between the measured temperature and the ambient temperature at the same elevation, computed on the basis of the results described in Sect. 4.2 (i.e., hourly variable lapse rate below Bel_3328 and fixed calibrated lapse rate above it). The average seasonal cooling effect (Table 4) was maximal at Car-gl_3082 $\left(-1.01^{\circ} \mathrm{C}\right.$ in 2011) and at Margl_2973 $\left(-0.74{ }^{\circ} \mathrm{C}\right.$ in 2010 and $-0.90^{\circ} \mathrm{C}$ in 2011). Null or negligible cooling was detected at Mar-gl_3438, close to the top of La Mare Glacier, and at Car-gl_3144 on the small Careser Occidentale Glacier. Minor cooling occurred at Mar-gl_3215 $\left(-0.27^{\circ} \mathrm{C}\right.$ in 2010$)$, which was close to the balanced-budged ELA of the glacier, and at Mar-gl_3140 $\left(-0.47^{\circ} \mathrm{C}\right.$ in 2011$)$, in the upper ablation area. Notably, the narrow and steep terminus of La Mare Glacier experienced a significant cooling effect in $2010\left(-0.65^{\circ} \mathrm{C}\right)$.

Figure 4 reports the mean daily cycles of the cooling effect and wind regime. A common pattern emerges, with minimum cooling at night and maximum cooling around noon or in the afternoon, coherent with the diurnal cycle of ambient air temperature and deriving temperature differences from the glacier surface. For five out of the seven moni- 
Table 3. Validation statistics for ambient temperature calculations (global data set including summer 2010 and 2011 )*

\begin{tabular}{|c|c|c|c|c|c|c|c|}
\hline \multirow[t]{2}{*}{$\begin{array}{l}\text { Lapse rate } \\
\left({ }^{\circ} \mathrm{Cm}^{-1}\right)\end{array}$} & \multirow[t]{2}{*}{$\begin{array}{l}\text { Used weather } \\
\text { stations }\end{array}$} & \multicolumn{3}{|c|}{$\begin{array}{l}\text { Calculation of air temperature } \\
\text { at Car_3051 }\end{array}$} & \multicolumn{3}{|c|}{$\begin{array}{c}\text { Calculation of air temperature } \\
\text { at Bel_3328 }\end{array}$} \\
\hline & & $\begin{array}{l}\text { Mean error } \\
\left({ }^{\circ} \mathrm{C}\right)\end{array}$ & $\begin{array}{l}\text { RMSE } \\
\left({ }^{\circ} \mathrm{C}\right)\end{array}$ & $\begin{array}{l}\text { N\&S } \\
\text { index }\end{array}$ & $\begin{array}{c}\text { Mean error } \\
\left({ }^{\circ} \mathrm{C}\right)\end{array}$ & $\begin{array}{l}\text { RMSE } \\
\left({ }^{\circ} \mathrm{C}\right)\end{array}$ & $\begin{array}{l}\text { N\&S } \\
\text { index }\end{array}$ \\
\hline \multicolumn{8}{|c|}{ Moist adiabatic lapse rate } \\
\hline-0.0065 & 1 & -1.14 & 3.81 & -0.019 & -0.51 & 3.59 & 0.276 \\
\hline-0.0065 & 2 & 0.59 & 1.32 & 0.878 & 1.22 & 2.02 & 0.771 \\
\hline-0.0065 & 3 & 1 & 1 & 1 & 0.63 & 1.46 & 0.880 \\
\hline-0.0065 & 4 & -0.63 & 1.46 & 0.851 & 1 & 1 & 1 \\
\hline \multicolumn{8}{|c|}{ Fixed calibrated lapse rate } \\
\hline-0.0053 & 1,2 & 1.13 & 1.64 & 0.812 & 2.11 & 2.65 & 0.605 \\
\hline-0.0059 & 1,3 & 1 & 1 & 1 & 0.81 & 1.54 & 0.866 \\
\hline-0.0063 & 1,4 & -0.70 & 1.49 & 0.845 & 1 & 1 & 1 \\
\hline-0.0078 & 2,3 & 1 & 1 & 1 & 0.27 & 1.34 & 0.899 \\
\hline-0.0082 & 2,4 & -0.17 & 1.32 & 0.877 & 1 & $\backslash$ & $\backslash$ \\
\hline-0.0057 & $1,2,3$ & 1 & 1 & 1 & 0.85 & 1.56 & 0.863 \\
\hline-0.0061 & $1,2,4$ & -0.74 & 1.51 & 0.841 & 1 & 1 & 1 \\
\hline \multicolumn{8}{|c|}{ Hourly variable lapse rate } \\
\hline Hourly variable & 1,2 & 1.13 & 1.55 & 0.831 & 2.11 & 2.89 & 0.529 \\
\hline Hourly variable & 1,3 & 1 & 1 & 1 & 0.81 & 1.74 & 0.830 \\
\hline Hourly variable & 1,4 & -0.70 & 1.51 & 0.840 & 1 & $\backslash$ & $\backslash$ \\
\hline Hourly variable & 2,3 & 1 & 1 & 1 & 0.27 & 1.64 & 0.849 \\
\hline Hourly variable & 2,4 & -0.17 & 1.01 & 0.929 & 1 & $\backslash$ & $\backslash$ \\
\hline Hourly variable & $1,2,3$ & 1 & 1 & 1 & 0.85 & 1.76 & 0.826 \\
\hline Hourly variable & $1,2,4$ & -0.74 & 1.55 & 0.831 & 1 & 1 & 1 \\
\hline
\end{tabular}

Table 4. Mean values of cooling effect, wind speed, and wind direction recorded at the on-glacier weather stations.

\begin{tabular}{|c|c|c|c|}
\hline Weather station & $\begin{array}{c}\text { Mean cooling } \\
\text { effect } \\
\left({ }^{\circ} \mathrm{C}\right)\end{array}$ & $\begin{array}{l}\text { Mea } \\
\text { speed } \\
\left(\mathrm{ms}^{-1}\right)\end{array}$ & $\begin{array}{l}\text { wind } \\
\text { direction } \\
\left(^{\circ}\right)\end{array}$ \\
\hline \multicolumn{4}{|l|}{ Summer 2010} \\
\hline Mar-gl_2709 & -0.65 & 2.00 & 247 \\
\hline Mar-gl_2973 & -0.74 & 3.13 & 230 \\
\hline Mar-g1_3215 & -0.27 & 3.47 & 258 \\
\hline \multicolumn{4}{|l|}{ Summer 2011} \\
\hline Mar-g1_2973 & -0.90 & 2.82 & 224 \\
\hline Mar-gl_3140 & -0.47 & 3.00 & 239 \\
\hline Mar-gl_3438 & 0.06 & 1 & 1 \\
\hline Car-gl_3082 & -1.01 & 2.40 & 249 \\
\hline Car-gl_3144 & -0.18 & 1.98 & 90 \\
\hline
\end{tabular}

tored sites, the cooling occurred almost exclusively during daytime. Nighttime cooling took place only at Mar-gl_2973 and Car-gl_3082, which are the two sites with higher mean cooling. Down-glacier winds dominated on La Mare Glacier, with higher speeds compared to Careser Occidentale and Orientale glaciers where up-glacier winds prevailed. The wind speed was at its maximum at night on La Mare, especially in 2010, while it was at its maximum in the afternoon on the two Careser glaciers. A peculiar behavior was found at the terminus of La Mare Glacier (Mar-gl_2709), where downglacier winds dominated at night, without a cooling effect, and were replaced by up-glacier winds from mid-morning to late afternoon, when the cooling effect increased sharply. Wind data were not available at Mar-gl_3438 due to instrumentation failure, but we can argue that katabatic winds were not prevalent at this site, which is close to the crest, based on results published for similar locations in previous works (e.g., Greuell et al., 1997; Strasser et al., 2004).

Different weather conditions led to a considerable temporal variability of the glacier cooling effect during the two summer seasons of 2010 and 2011 (Fig. 5). Cooling was maximal during warm anticyclonic periods and nearly absent during cold unsettled weather. Differences among sites increased with warmer temperatures, whereas they nearly disappeared during cold and unstable periods. The highest vari- 

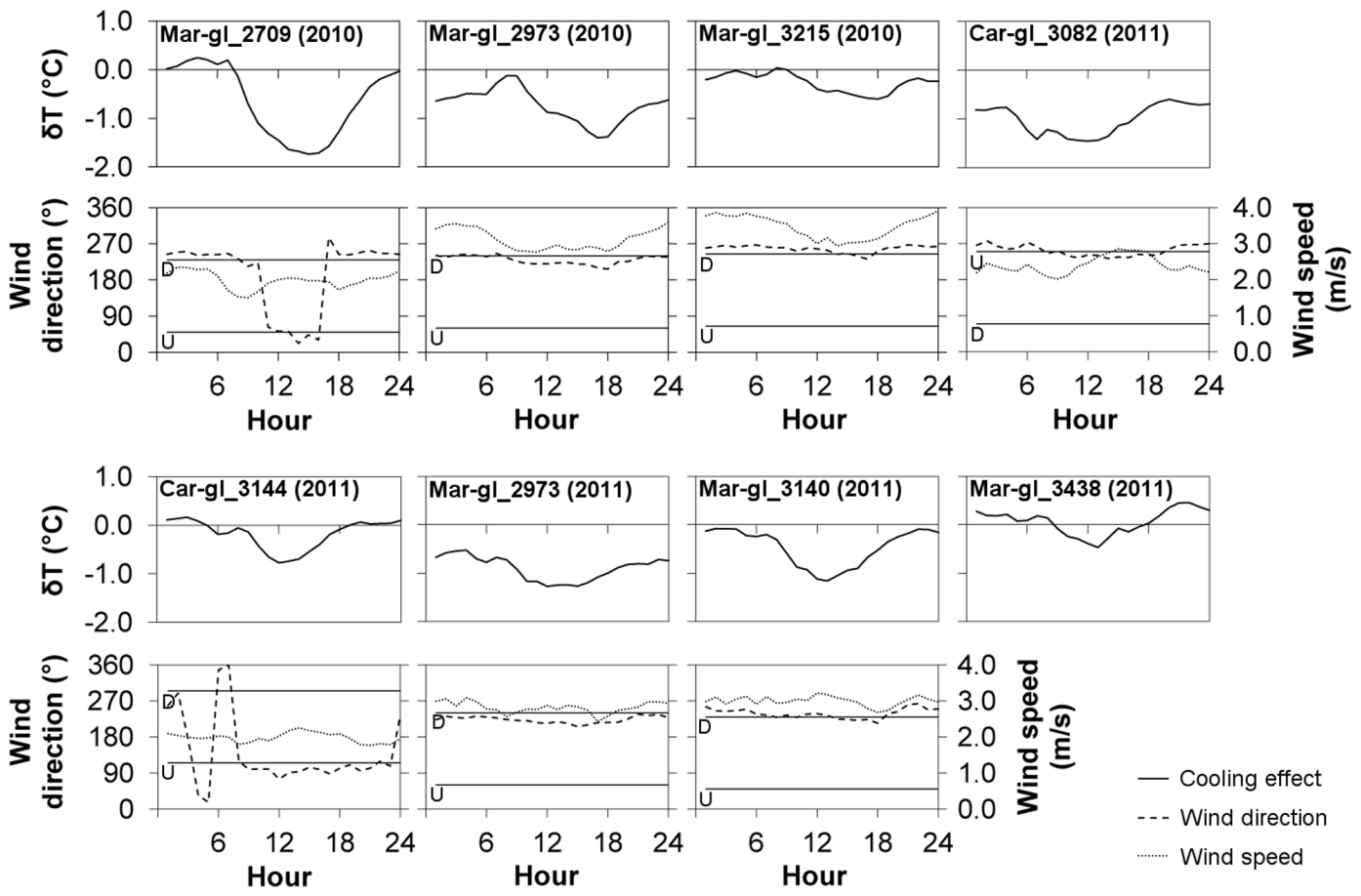

Figure 4. Mean daily cycle of the glacier cooling effect $(\delta T)$, wind direction, and wind speed at the eight on-glacier weather stations. The operation period of each station is indicated in parentheses. Down-glacier and up-glacier wind directions are indicated with straight lines marked with "D" and "U". Mar-gl_3438 lacks wind data because of anemometer failure.

ations occurred at Mar-gl_2973, Mar-gl_3215, Mar-gl_3140, and Car-gl_3082, while at Mar-gl_3438 and Car-gl_3144 there was a smaller temporal variability. A warming, rather than cooling, effect was observed on some days, mainly at the upper weather stations of La Mare Glacier. A close check on the wind and temperature data revealed that this was ascribable to local föhn conditions, that is, forced adiabatic heating brought by strong northerly winds.

\subsection{Calculation of on-glacier temperature from off-site data}

According to the S\&M method, piecewise linear regressions of on-glacier hourly temperature vs. ambient temperature at the same elevation have been calculated for each glacial weather station. The values of the parameters $k_{1}$ and $k_{2}$ (i.e., temperature sensitivities for ambient temperatures below and above the threshold temperature $T^{*}$, respectively) were well aligned with the transfer functions proposed by $\mathrm{S} \& \mathrm{M}$, using the FPL as predictor (Fig. 6). However, the transfer function for $T^{*}$ suggested by $\mathrm{S} \& \mathrm{M}$, using station elevation as a predictor, could not be used in AVDM given the different geographic and climatic setting of the two study areas. We therefore propose to substitute Eq. (2) with the following function:

$T^{*}=\frac{a \cdot \mathrm{FPL}}{b+\mathrm{FPL}}$, which uses the FPL (m) rather than elevation as a predictor, thus being potentially more generalizable. Neither the outlier already excluded by S\&M nor Mag-gl_2709 was included in our calculation of Eq. (12) due to undersampling at below-zero temperatures. Figure 6 shows data points, transfer functions, and parameters. Calculated vs. measured temperature is shown in Fig. 7 along with related statistics. Four out of the five sites where the method works satisfactorily ( $\mathrm{ME}<0.5^{\circ} \mathrm{C}$ in absolute value and $\mathrm{N} \& \mathrm{~S}$ index $>0.87$ ) have prevailing katabatic winds. Contrarily, lower performance affects sites close to the glacier margin (Margl_3438 and, in particular, Mar-gl_2709), where katabatic winds are disrupted by valley winds or synoptic winds, and Car-gl_3082, where up-glacier winds prevail. The efficiency statistics for all sites are $\mathrm{ME}=-0.06^{\circ} \mathrm{C}, \mathrm{RMSE}=0.73^{\circ} \mathrm{C}$, and $\mathrm{N} \& \mathrm{~S}=0.692$.

According to the G\&B method, the location $x_{0}$ where the air enters the glacier wind layer and the length scale $L_{R}$ can be calculated by an exponential function which expresses the "climatic sensitivity" in function of the distance $x$ along the flow line:

$\frac{\mathrm{d} T(x)}{\mathrm{d} T_{\mathrm{cs}}}=\exp \left(-\frac{x+x_{0}}{L_{\mathrm{R}}}\right)$.

Climatic sensitivities were calculated, comparing daily mean temperature at our on-glacier sites to daily mean temperature at Car_3051 and have been added for comparison to the data 

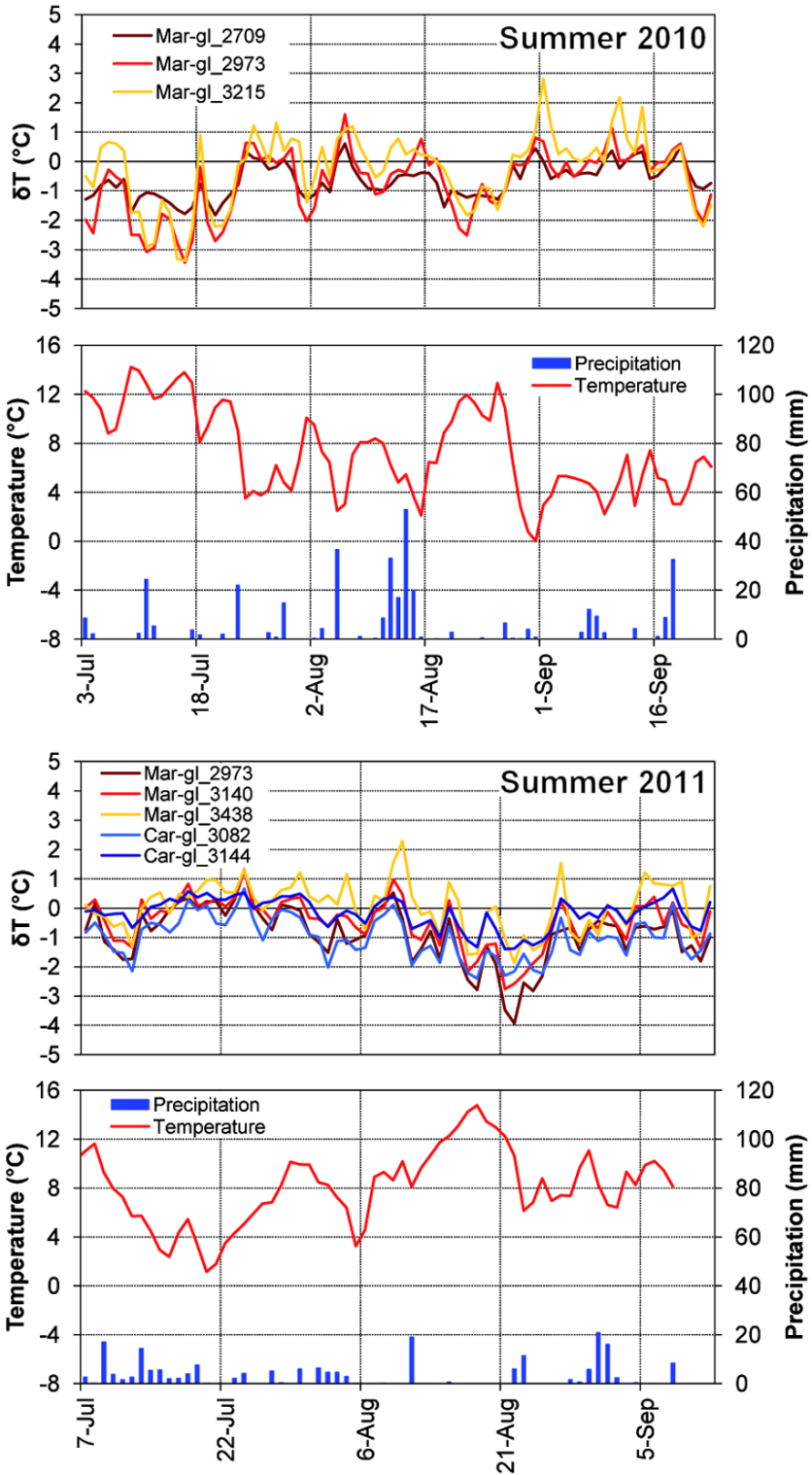

Figure 5. Mean daily cooling effect at the on-glacier weather stations and corresponding daily precipitation and mean temperature at Careser Diga (Car_2607).

displayed in Fig. 5 of the Greuell and Böhm (1998) paper. The results are shown in Fig. 8 and indicate a fairly good alignment of our data with the other glaciers' data and with the best fit calculated by G\&B for the Pasterze weather stations. It therefore seemed appropriate to use the values of $x_{0}$ and $L_{\mathrm{R}}$ calculated by those authors, that is, 1440 and $8340 \mathrm{~m}$, respectively. According to the $G \& B$ procedure, the hourly temperature above the freezing level was set equal to the ambient temperature (Sect. 4.2). Below the freezing level, the glacier-wind model of G\&B was applied, setting (i) $x_{0}=0$ when the freezing level was below the top of the flow line and (ii) $x_{0}=1440 \mathrm{~m}$ when it was above this point in order to
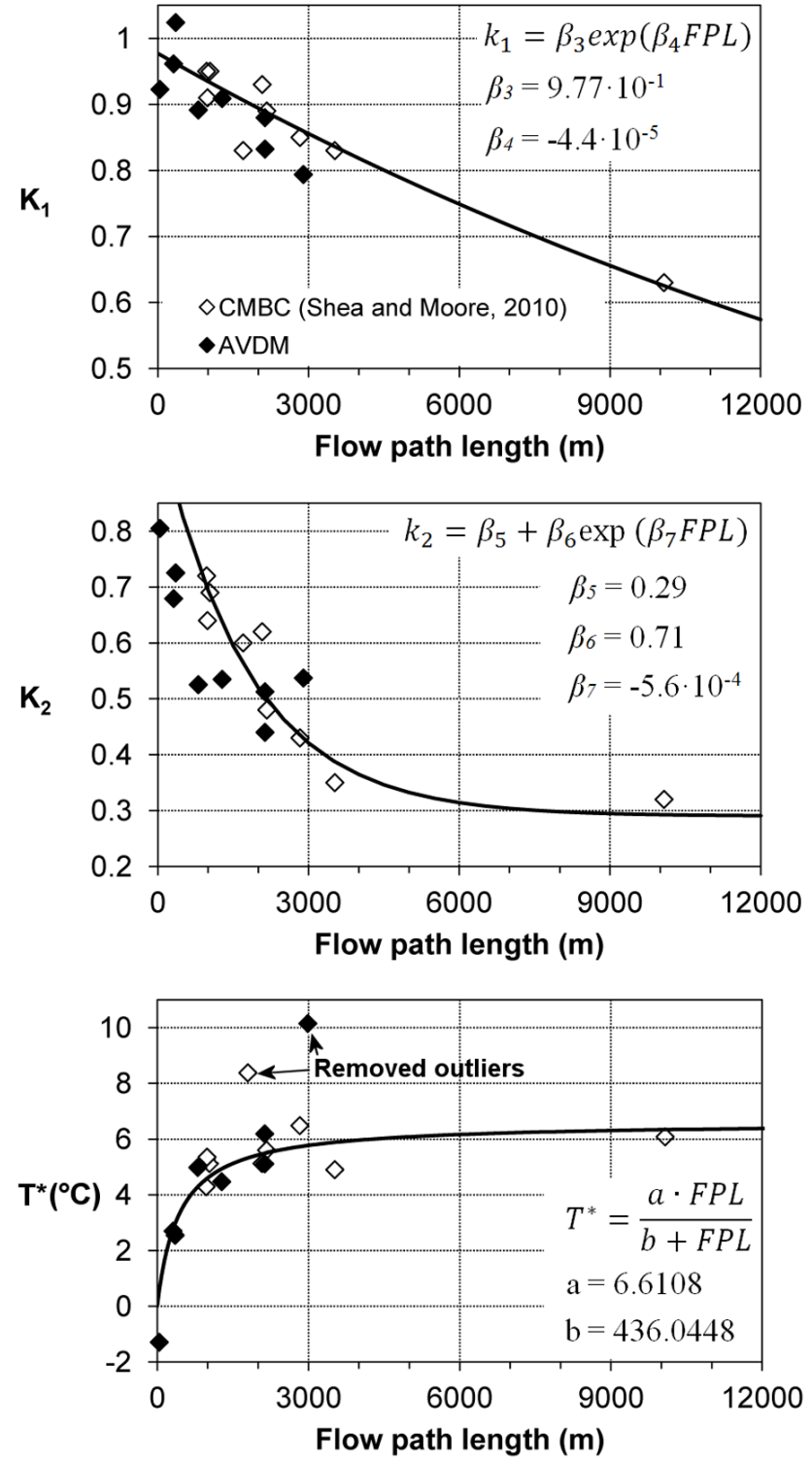

Figure 6. Transfer functions for the coefficients $K_{1}, K_{2}$, and $T^{*}$ of the Shea and Moore (2010) method. CMBC is the S\&M study area; AVDM is our study area. Outliers due to undersampling at freezing temperatures have been removed (as in the $\mathrm{S} \& \mathrm{M}$ work). $\beta_{3}$ to $\beta_{7}$ are coefficients from S\&M (J. M. Shea, personal communication, 2014), while the transfer function and coefficients for $T^{*}$ are new results from the present work.

take into account a climate sensitivity $<1$ at the top of the flow line. $z_{0}$ was set equal to the freezing level in case (i) and equal to the altitude of the top of the flow line in case (ii). These settings are the same as those used in the G\&B paper. Nevertheless, no corrections were applied to the computed temperatures, as was done by $\mathrm{G} \& \mathrm{~B}$, who applied a fixed offset of $-0.74^{\circ} \mathrm{C}$.

Figure 9 displays the results of the G\&B method. Calculated temperatures matched the measured temperatures fairly 

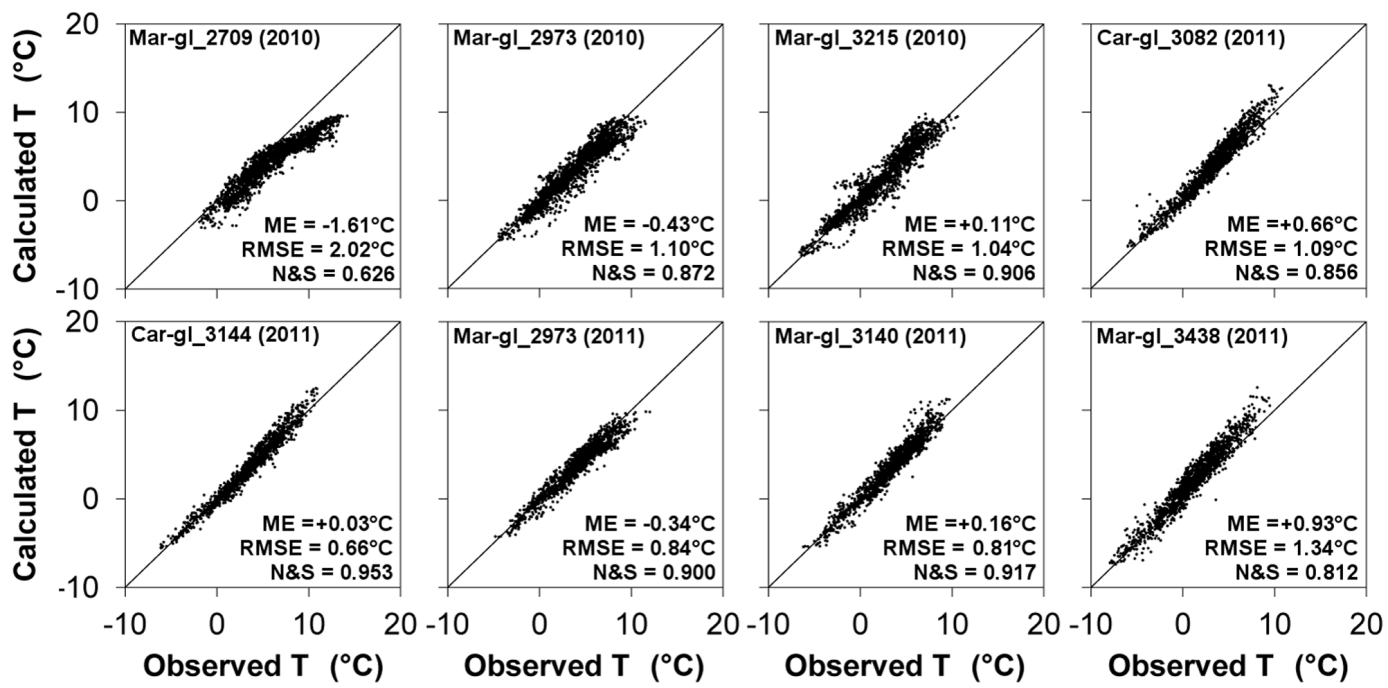

Figure 7. On-glacier temperature calculated with the Shea and Moore (2010) method vs. observed temperature.

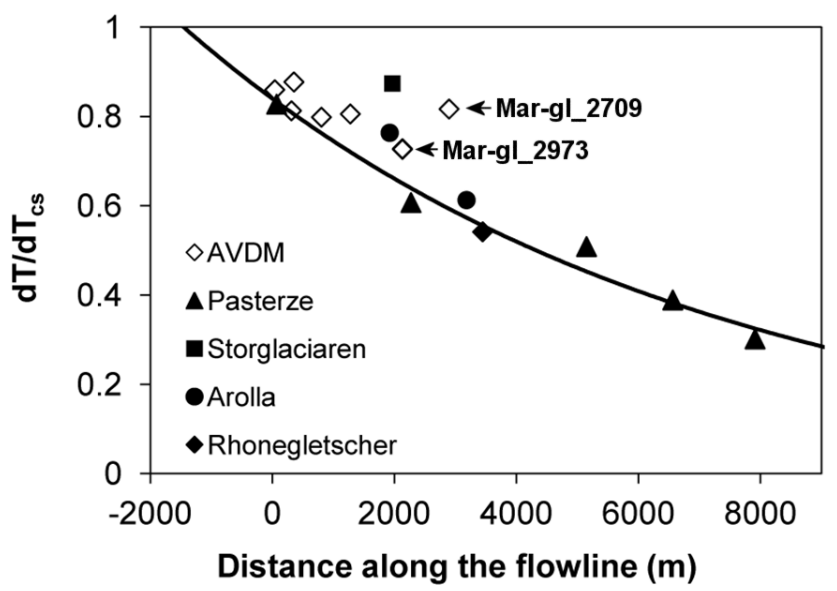

Figure 8. Sensitivity of on-glacier temperature to temperature outside the thermal influence of glaciers and best fit of Eq. (13) to Pasterze data. Redrawn figure from Greuell and Böhm (1998). Values measured on Careser and La Mare glaciers (AVDM) have been added for comparison. Mar-gl_2973: two overlapping points (summer 2010 and 2011 have identical sensitivity).

well and the efficiency statistics for all sites were better than for the S\&M method: $\mathrm{ME}=-0.27^{\circ} \mathrm{C}$, $\mathrm{RMSE}=0.40^{\circ} \mathrm{C}$, $\mathrm{N} \& \mathrm{~S}=0.908$. Improvements were observed, in particular, at Mar-gl_2709, Car-gl_3082, and Mar-gl_3438, even if these sites lack predominant katabatic winds. A clear step is observable at Mar-gl_2709 and, slightly less obvious, at Margl_2973 in both summer 2010 and 2011, attributable to the jump of $x_{0}$ from 0 to $1440 \mathrm{~m}$ when the freezing level exceeds the top of the flow line.

\subsection{Mass balance modeling}

EISModel applications using measured temperature data sets resulted in RMSE values well below the mass balance measurement error from ablation stakes readings $(\sim 200 \mathrm{~mm}$ w.e., Thibert et al., 2008; Huss et al., 2009), thus confirming the good skill of the modeling tool. However, the RMSE was nearly double when calculated temperature data sets were used as input, and considerable differences also exist in the calibration parameters (Table 5).

The spatial distribution of modeling errors using temperature extrapolations from Car_2607 via the standard lapse rate (Fig. 10, scatterplots b1-b4) replicated the findings of Carturan et al. (2012a) for the 6 previous years (2004-2009). In particular, the modeled vertical gradient of mass balance on La Mare Glacier in summer 2010 was lower than the observed one, in both calibration and validation runs, due to uneven errors in estimating air temperature $(+0.77,+1.17$, and $+1.14{ }^{\circ} \mathrm{C}$ at Mar-gl_2709, Mar-gl_2973, and Mar-gl_3215, respectively). This data set of overestimated temperatures led to significantly lower calibration parameters compared to the measured temperature data set. Moreover, including critical points close to the lower margin of the glacier (Mar-gl_2709 in summer 2010) led to wrong calibration at the other two points, which are likely to have a higher spatial representativeness given the larger distance from the glacier margin.

The calibration parameters obtained with the G\&B temperature data set were closer to those obtained with the measured temperature data set, as could be expected given the smaller errors in temperature estimations (Fig. 9). In summer 2010, modeling results with the G\&B temperature data set were also the best among the three tested methods for air temperature calculation, in both calibration and validation runs. The same cannot be stated for summer 2011 due to the larger temperature underestimation at Mar-gl_3140 and Car- 

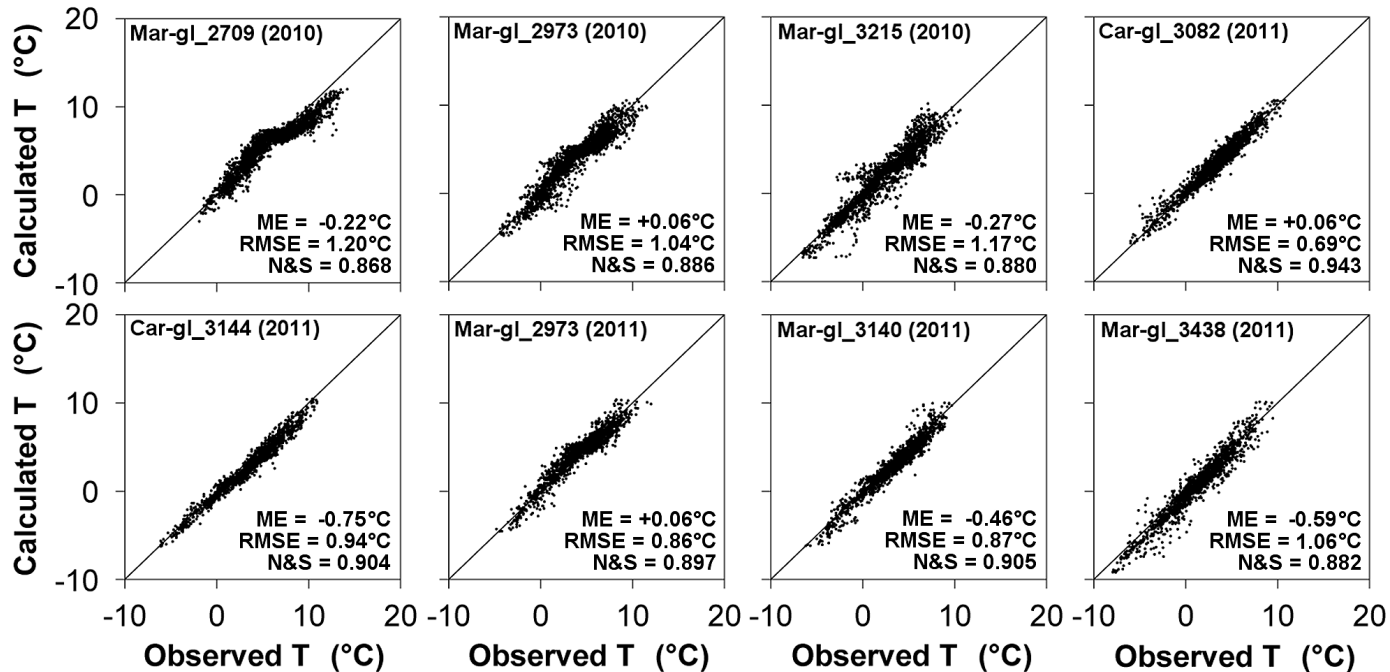

Figure 9. On-glacier temperature calculated with the G\&B method vs. observed temperature.

gl_3144. Similar errors occurring at Mar-gl_3438 did not impact mass balance estimations because they mainly happened at below-zero temperatures (Fig. 9).

The S\&M temperature data set led to the worst results in summer 2010 due to the strong underestimation of air temperature at Mar-gl_2709 $\left(-1.6^{\circ} \mathrm{C}\right)$. Calibrated parameters in 2010 were thus overestimated and led to mass balances that were too negative, on average, in 2011. On the contrary, when used for calibration, the data of 2011 led to parameters much closer to the measured temperature data set, leading to correct mass balance estimations in summer 2010 with the exception of the already mentioned Mar-gl_2709.

\section{Discussion}

The temperature distribution and wind regime were found to be remarkably different for the three investigated glaciers (Tables 2 and 4, Fig. 4). The most significant differences were detected between La Mare Glacier, where the KBL and the cooling effect were clearly recognizable, and Careser Occidentale Glacier, where the air temperature was not significantly different from the ambient temperature and where prevailing up-glacier winds (i.e., valley winds) dominated. Differences were even more prominent during warm and stable weather (Fig. 5), brought by persistent anticyclonic systems (as detected by inspection of reanalysis weather charts from www.wetterzentrale.de, last access: 31 October 2014).

The Car-gl_3082 site, on Careser Orientale Glacier, also displayed peculiar conditions compared to most weather stations operated on La Mare Glacier. On the one hand, a prevailing up-glacier wind was recognized, but it cannot be attributed unequivocally to valley winds because the direction roughly corresponds to prevailing synoptic winds in the Ortles-Cevedale area (Gabrieli et al., 2011). The occurrence of weaker local winds and more relevant entrainment of synoptic winds have been hypothesized, for example, by Ayala et al. (2015), for glaciers without a well-defined tongue. On the other hand, although katabatic flows were generally absent, this site was the coldest in summer 2011, exhibiting a mean depression of $1{ }^{\circ} \mathrm{C}$ compared to the ambient temperature (Table 4). In addition, during warm anticyclonic periods it displayed a cooling effect similar to Mar-gl_2973 and Margl_3140, located in the middle part of La Mare Glacier. This is unusual for locations close to the top of glacier flow lines, which normally display a low cooling effect and high temperature sensitivity (e.g., Greuell and Böhm, 1998; Shea and Moore, 2010; Petersen et al., 2013). The efficient cooling at Car-gl_3082 could have been caused by the combination of adiabatic cooling of ascending air and cooling by loss of sensible heat due to the rather long fetch $(780 \mathrm{~m}$ from the lower edge of the glacier), whereas in katabatic flows the loss of sensible heat is to some extent compensated by the adiabatic heating of descending air (Greuell and Böhm, 1998).

The behavior of the two weather stations on Careser Occidentale and Orientale glaciers provides evidence of the reduced effectiveness of small glaciers (deriving from the fragmentation of larger glaciers) in cooling the air above compared to wider glaciers or wider portions of the same parent glacier. This is suggested by the fact that these two weather stations (Car-gl_3082 and Car-gl_3144), despite being at almost the same flow path distance from the upper glacier margin (Table 1, Fig. 2), have very different cooling effects (Table 4, Fig. 4) which largely explain errors in modeled ablation rates (Fig. 10; Fig. 8 from Carturan et al., 2012a).

In consideration of the high number and contribution to the world's total ice volume of smaller glaciers (Haeberli et al., 1989; Paul et al., 2004; Zemp et al., 2008; Bahr and Radić, 2012), and given the absence of previous experimental data from such small ice bodies these results provide a first 


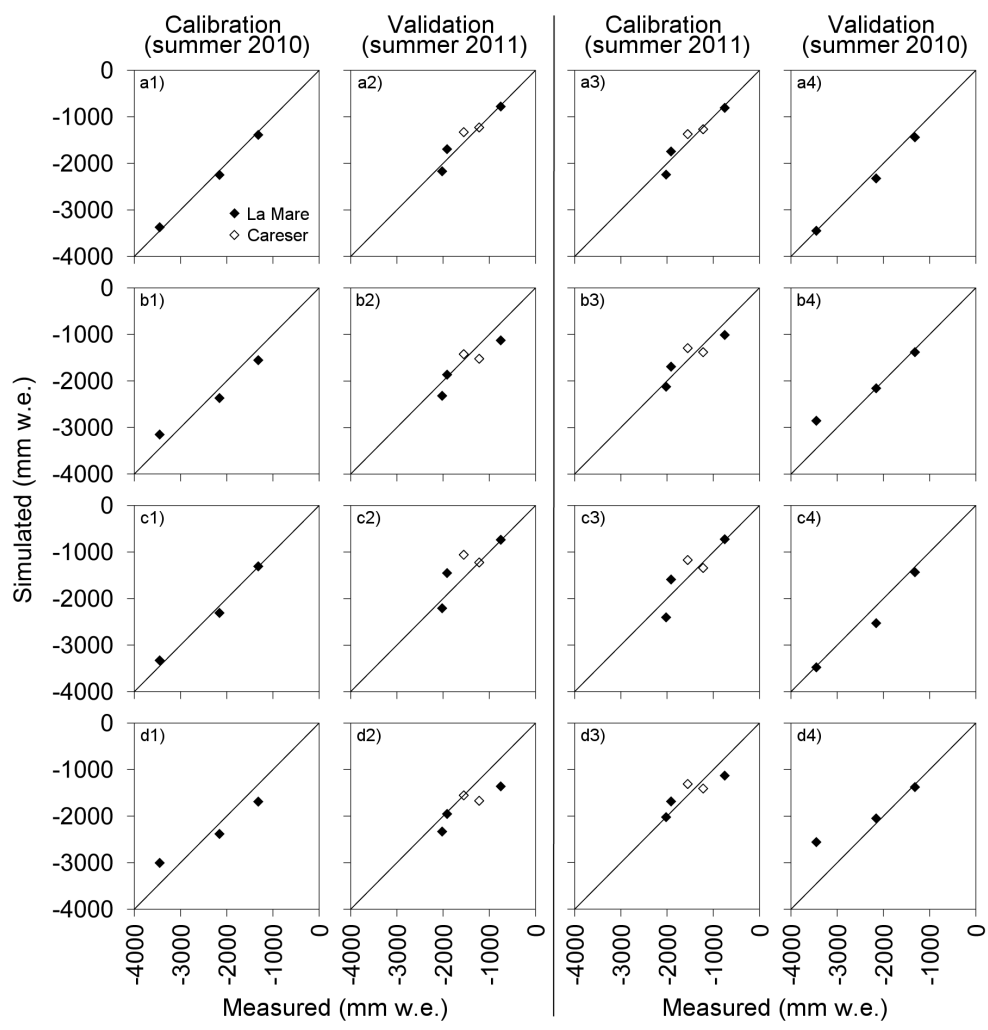

Figure 10. Measured vs. modeled mass balance at the eight glacial weather stations, using EISModel with four different air temperature inputs: (a1-a4) measured, (b1-b4) extrapolated from Car_2607 via the standard lapse rate $\left(-6.5^{\circ} \mathrm{C} \mathrm{km}^{-1}\right)$, (c1-c4) calculated via the G\&B method, and (d1-d4) calculated via the S\&M method. Corresponding statistics are reported in Table 5.

quantification for an important reinforcing mechanism during glacier decay, that is, the disintegration of parent glaciers into smaller units, which have reduced effectiveness in cooling the air above and in triggering katabatic flows. Clearly, these results are not conclusive and require further experimental data to assess their generalizability and to develop generalized strategies for calculating air temperature over glaciers with similar characteristics, to be implemented in distributed mass balance models.

A clear dependency of air temperature on elevation was found on La Mare Glacier, where the weather stations were placed along a longitudinal profile, exploring a large range of elevations (Fig. 3). The on-glacier lapse rate was steeper than the standard ambient lapse rate, unlike in previous works which mostly report shallower values ranging from -2.8 to $-8.1^{\circ} \mathrm{Ckm}^{-1}$ and averaging $-4.9^{\circ} \mathrm{Ckm}^{-1}$ (Petersen and Pellicciotti, 2011, and references cited therein; Petersen et al., 2013). The steep lapse rate measured on La Mare Glacier is likely due to its physical characteristics and to the specific location of weather stations. For example, Mar-gl_2973, which is located $2.13 \mathrm{~km}$ downslope from the upper margin of the glacier, displayed only a moderate cooling effect $\left(-0.74^{\circ} \mathrm{C}\right.$ in 2010 and $-0.90^{\circ} \mathrm{C}$ in 2011$)$ due to the presence of a steep slope causing adiabatic heating right above the weather station. An even more unusual behavior was measured at Mar-gl_2709, close to the terminus of the glacier. Here the cooling effect was detected only during daytime, with valley winds prevailing over katabatic winds, while at night the adiabatic heating of the air descending the steep tongue prevailed over the cooling due to turbulent exchanges. Besides the physical characteristics of the glacier, however, the steep lapse rates might also have been influenced by the steep lapse rate measured outside the thermal influence of glaciers.

The specific reasons for the steepness of the high-altitude ambient lapse rates are not easy to identify. According to Marshall et al. (2007) and Minder et al. (2010), for example, they could have been caused by the prevailing synoptic circulation, local energy balance regime, persistence of snow cover, or geographic position (windward or leeward with respect to the prevailing synoptic wind). Apart from these considerations, it has to be noted that the interpolation and extrapolation of ambient temperature at high altitudes, as a starting point for the computation of the on-glacier temperature fields, are strongly dependent on the availability and/or selection of suitable weather stations. As already suggested, e.g., by Oerlemans (2001), measurements from high-altitude weather stations are preferable to measurements from valley- 
Table 5. Calibration parameters and mass balance statistics from EISModel applications with four different data sets of air temperature*.

\begin{tabular}{|c|c|c|c|c|c|c|c|c|}
\hline \multirow[t]{2}{*}{$\begin{array}{l}\text { Temperature } \\
\text { data set }\end{array}$} & \multicolumn{2}{|c|}{$\begin{array}{l}\text { Calibrated } \\
\text { parameters }\end{array}$} & \multicolumn{3}{|c|}{$\begin{array}{l}\text { Calibration run } \\
\text { (summer 2010) }\end{array}$} & \multicolumn{3}{|c|}{$\begin{array}{l}\text { Validation run } \\
\text { (summer 2011) }\end{array}$} \\
\hline & $\begin{array}{c}\mathrm{TMF} \\
\left(\mathrm{mmh}^{-1}{ }^{\circ} \mathrm{C}^{-1}\right)\end{array}$ & $\begin{array}{c}\text { RMF } \\
\left(\mathrm{mmh}^{-1} \mathrm{~W}^{-1} \mathrm{~m}^{2}\right)\end{array}$ & $\begin{array}{c}\text { ME } \\
\text { (m w.e.) }\end{array}$ & $\begin{array}{l}\text { RMSE } \\
\text { (m w.e.) }\end{array}$ & $N \& S$ & $\begin{array}{c}\text { ME } \\
\text { (m w.e.) }\end{array}$ & $\begin{array}{l}\text { RMSE } \\
\text { (m w.e.) }\end{array}$ & $\mathrm{N} \& \mathrm{~S}$ \\
\hline Measured temperature & 0.246 & 0.00117 & -0.027 & 0.080 & 0.992 & +0.052 & 0.156 & 0.888 \\
\hline Standard lapse rate & 0.202 & 0.00100 & -0.049 & 0.252 & 0.918 & -0.160 & 0.261 & 0.686 \\
\hline G\&B method & 0.251 & 0.00109 & -0.006 & 0.113 & 0.984 & +0.156 & 0.314 & 0.545 \\
\hline \multirow[t]{3}{*}{ S\&M method } & 0.291 & 0.00128 & -0.049 & 0.359 & 0.832 & -0.282 & 0.366 & 0.381 \\
\hline & \multicolumn{2}{|c|}{$\begin{array}{l}\text { Calibrated } \\
\text { parameters }\end{array}$} & \multicolumn{3}{|c|}{$\begin{array}{l}\text { Calibration run } \\
\text { (summer 2011) }\end{array}$} & \multicolumn{3}{|c|}{$\begin{array}{l}\text { Validation run } \\
\text { (summer 2010) }\end{array}$} \\
\hline & $\begin{array}{c}\text { TMF } \\
\left(\mathrm{mmh}^{-1}{ }^{\circ} \mathrm{C}^{-1}\right)\end{array}$ & $\begin{array}{c}\text { RMF } \\
\left(\mathrm{mmh}^{-1} \mathrm{~W}^{-1} \mathrm{~m}^{2}\right)\end{array}$ & $\begin{array}{c}\text { ME } \\
\text { (m w.e.) }\end{array}$ & $\begin{array}{l}\text { RMSE } \\
\text { (m w.e.) }\end{array}$ & $N \& S$ & $\begin{array}{c}\text { ME } \\
\text { (m w.e.) }\end{array}$ & $\begin{array}{l}\text { RMSE } \\
\text { (m w.e.) }\end{array}$ & $N \& S$ \\
\hline Measured temperature & 0.246 & 0.00138 & +0.006 & 0.152 & 0.893 & -0.095 & 0.119 & 0.982 \\
\hline Standard lapse rate & 0.175 & 0.00111 & -0.008 & 0.210 & 0.796 & +0.178 & 0.346 & 0.844 \\
\hline G\&B method & 0.265 & 0.00141 & +0.045 & 0.288 & 0.618 & -0.172 & 0.226 & 0.934 \\
\hline S\&M method & 0.236 & 0.00129 & -0.018 & 0.241 & 0.732 & +0.315 & 0.522 & 0.647 \\
\hline
\end{tabular}

* Calibration in 2010 and validation in 2011 in the upper table, vice versa in the lower table. Measured vs. modeled values are displayed in Fig. 10.

floor sites, which are prone to thermal inversions and subject to high temperature oscillations during the day.

The good alignment of our data points with the transfer functions of Shea and Moore (2010), which can be seen in Fig. 6, is remarkable given the different characteristics of glaciers and geographic setting of the two study areas. This result points to a good generalizability of the S\&M method, which we have tried to improve by implementing a transfer function for $T^{*}$ based on the FPL rather than on elevation. The S\&M method was fairly successful at sites where the KBL was detected (Mar-gl_3140, Mar-gl_3215), that is, for the conditions under which the method has been implemented. Nevertheless, at Mar-gl_2973 it significantly underestimated the temperature, probably because it does not account for gradients upslope of the weather station, which causes a local prevalence of adiabatic heating. A larger error occurred at Mar-gl_2709, which is, however, influenced by valley winds and thermal emission from the surrounding bare rocks, determining high temperature sensitivity and unusual $T^{*}$ at such a long FPL (2896 m, Fig. 6). With this method it was not possible to reproduce the temperature differences between Car-gl_3082 and Car-gl_3144, as expected, because they have similar values of down-glacier FPL (313 and $354 \mathrm{~m}$, respectively).

The G\&B method provided the best overall results. Among sites with prevailing katabatic winds, the improvement was clearest at Mar-gl_2973, where the method was able to account for the combined effect of adiabatic heating and turbulent exchanges, which were regulated by the slope variations along the upstream flow line. However, it was worse than the S\&M method at distinguishing between the two Careser glaciers, and the better results in terms of lower mean errors at Mar-gl_2709, Mar-gl_3438 and Cargl_3082, compared to the S\&M method, are coincidental because at these sites the KBL was almost absent or not prevailing.

Other combinations of parameters $x_{0}$ and $L_{\mathrm{R}}$ have been tested to evaluate whether they are valid alternatives, for example for eliminating the artificial step in calculated vs. observed temperature at Mar-gl_2973 and Mar-gl_2709 (Fig. 9) caused by the jump of $x_{0}$ from 0 to $1440 \mathrm{~m}$ when the freezing level exceeds the top of the flow line. The tested combinations were (i) $x_{0}=0 \mathrm{~m}$ (constant) and $L_{\mathrm{R}}=8340 \mathrm{~m}$, (ii) $x_{0}=1440 \mathrm{~m}$ (constant) and $L_{\mathrm{R}}=8340 \mathrm{~m}$, and (iii) $x_{0}=$ $1835 \mathrm{~m}$ (constant) and $L_{\mathrm{R}}=12682 \mathrm{~m}$. The last combination results from the best fit to AVDM data in Fig. 8, excluding the outlier Mar-gl_2709. We also tested the calculation using the unmodified ambient temperature. Tests indicate that at sites with almost no cooling effect (Mar-gl_3438 and Cargl_3144) the unmodified ambient temperature or the combination (i) $\left(x_{0}=0\right)$ provide the best results (mean errors $<0.2{ }^{\circ} \mathrm{C}$ in absolute value). At the four sites with prevailing KBL the best overall solution was (iii), but this combination is specific for the AVDM and not generalizable due to the rather small size of our glaciers. At Mar-gl_2973, options (ii) and (iii) completely removed the step and provided the best statistics. At Mar-gl_3215, option (iii) provided almost identical results to a variable $x_{0}$, while options (i) and (ii) led to excessive overestimations and underestimations, respectively. At Mar-gl_3140, the best option was (iii).

These findings highlight site-specific and glacier-specific conditions which still need investigation in order to generalize the $G \& B$ procedure, possibly by including smaller or disintegrating glaciers in the data sets used for the general- 
ization. Sites where the KBL no longer exists and is replaced by prevailing valley winds and/or synoptic winds also need to be included as they reveal important controlling mechanisms during glacier shrinking, which require modifications to the main $G \& B$ algorithms in order to be taken into account.

The results of EISModel applications underline the importance of correct on-glacier air temperature estimation for reliable mass balance calculations (Table 5, Fig. 10). Even small estimation errors induce significant distortions in calibration parameters and compromise model generalizability. The 2010 data set on La Mare Glacier clearly demonstrates how single points, especially if they are displaced along altitudinal profiles, can affect the calibration of the model and its capability to account for the vertical gradients of the mass balance. This problem is clearly emphasized in our case study, with only three weather stations along the flow line of La Mare Glacier in 2010. The spatial representativeness of Mar-gl_2973 and Mar-gl_3215 is likely much higher than that of Mar-gl_2709 at the glacier terminus, which reflects the conditions close to the lower edge of glaciers. However, mass balance models should be improved in order to account for the decreased thermal offset in these areas and in smaller glacier units resulting from the fragmentation of larger glaciers, because they represent important processes involved in the response of glaciers to climatic changes.

\section{Concluding remarks}

The results of this work have interesting implications for the knowledge of glacier's reactions to climatic changes and for their modeling. The main conclusions from this study are the following:

1. Our findings provide a first experimental evidence for the reduced effectiveness of small glaciers $\left(<0.5 \mathrm{~km}^{2}\right)$ in cooling the air above and in triggering katabatic flows. This represents an important reinforcing mechanism during glacier decay and fragmentation.

2. A good match between our temperature measurements and the parameterizations proposed by Shea and Moore (2010) and, best of all, Greuell and Böhm (1998) was found, at least for the on-glacier weather stations where katabatic flows prevail. This represents a step forward for the generalization of these methods, which still need refinements in particular for areas close to the margins (e.g., the front) and for the smaller units resulting from glacier fragmentation.

3. Even small deviations of calculated on-glacier temperature from observations significantly impacted the calibration of EISModel and its efficiency, thus confirming that accurate temperature estimations are an essential prerequisite for model development, calibration, and generalizability.
Author contributions. L. Carturan, F. Cazorzi, and G. Dalla Fontana designed the glacial-meteorological experiment and carried it out. L. Carturan and F. De Blasi processed and analyzed the experimental data. F. Cazorzi and L. Carturan developed the EISModel and performed the glacier mass balance simulations. L. Carturan prepared the manuscript with contributions from all coauthors.

Acknowledgements. The data and the mass balance model used in this study can be made available upon request to the authors. This study was founded by the Italian MIUR project (PRIN 2010-11) "Response of morphoclimatic system dynamics to global changes and related geomorphological hazards" (local and national coordinators G. Dalla Fontana and C. Baroni). The authors acknowledge the autonomous province of Trento and Enel SpA for providing the meteorological and topographic data. Special thanks to Vinicio Carraro for the help in the setup of automatic weather stations and to the students, colleagues, and alpine guides who have contributed to the field surveys. Finally, thanks to the scientific editor V. Radic and to two anonymous reviewers, whose comments were helpful for finalizing the paper.

Edited by: V. Radic

\section{References}

Abbate, S., Avvenuti, M., Carturan, L., and Cesarini, D.: Deploying a communicating automatic weather station on an Alpine Glacier, Procedia Computer Science, 19, 1190-1195, 2013.

Ayala, A., Pellicciotti, F., and Shea, J. M.: Modeling $2 \mathrm{~m}$ air temperatures over mountain glaciers: Exploring the influence of katabatic cooling and external warming, J. Geophys. Res. Atmos., 120, doi:10.1002/2015JD023137, online first, 2015.

Bahr, D. B. and Radić, V.: Significant contribution to total mass from very small glaciers, The Cryosphere, 6, 763-770, doi:10.5194/tc-6-763-2012, 2012.

Barry, R. G.: The status of research on glaciers and global glacier recession: a review, Prog. Phys. Geog., 30, 285-306, 2006.

Braithwaite, R. J.: Regional modelling of ablation in West Greenland, Grønlands geologiske undersøgelse, 98, 20 pp., 1980.

Braithwaite, R. J., Zhang, Y., and Raper, S. C. B.: Temperature sensitivity of the mass balance of mountain glaciers and icecaps as a climatological characteristic, Zeitschrift fur Gletscherkunde und Glazialgeologie, 38, 35-61, 2002.

Carturan, L.: Climate change effects on the cryosphere and hydrology of a high-altitude watershed, $\mathrm{PhD}$ thesis, TeSAF - University of Padova, Padova, Italy, 2010.

Carturan, L., Dalla Fontana, G., and Cazorzi, F.: The mass balance of La Mare Glacier (Ortles-Cevedale, Italian Alps) from 2003 to 2008, in: Epitome - Geoitalia 2009, Settimo Forum Italiano di Scienze della Terra, Rimini, Italy, 9-11 September 2009, 3, p. 296, 2009.

Carturan, L., Cazorzi, F., and Dalla Fontana, G.: Distributed mass-balance modeling on two neighboring glaciers in OrtlesCevedale, Italy, from 2004 to 2009, J. Glaciol., 58, 467-486, 2012a. 
Carturan, L., Dalla Fontana, G., and Borga, M.: Estimation of winter precipitation in a high-altitude catchment of the Eastern Italian Alps: validation by means of glacier mass balance observations, GFDQ - Geografia Fisica e Dinamica Quaternaria, 35, 37-48, 2012b.

Carturan, L., Baroni, C., Becker, M., Bellin, A., Cainelli, O., Carton, A., Casarotto, C., Dalla Fontana, G., Godio, A., Martinelli, T., Salvatore, M. C., and Seppi, R.: Decay of a long-term monitored glacier: Careser Glacier (Ortles-Cevedale, European Alps), The Cryosphere, 7, 1819-1838, doi:10.5194/tc-7-1819-2013, 2013.

Carturan, L., Baroni, C., Carton, A., Cazorzi, F., Dalla Fontana, G., Delpero, C., Salvatore, M. C., Seppi, R., and Zanoner, T.: Reconstructing fluctuations of La Mare Glacier (Eastern Italian Alps) in the Late Holocene: new evidences for a Little Ice Age maximum around 1600 AD, Geogr. Ann. A, 96, 287-306, 2014.

Cazorzi, F. and Dalla Fontana, G.: Snowmelt modeling by combining air temperature and a distributed radiation index, J. Hydrol., 181, 169-187, 1996.

Charbonneau, R., Lardeau, J. P., and Obled, C.: Problems of modelling a high mountainous drainage basin with predominant snow yields, Hydrological Sciences Bulletin, 26, 345-361, 1981.

Davidovich, N. V. and Ananicheva, M. D.: Prediction of possible changes in glacio-hydrological characteristics under global warming: Southeastern Alaska, USA, J. Glaciol., 42, 407-412, 1996.

Eriksson, B. E.: Glaciological investigations in Jotunheimen and Sarek in the years 1955 to 1957, Geographica, 34, 208 pp., 1958.

Fischer, A.: Glaciers and climate change: interpretation of 50 years of direct mass balance of Hintereisferner, Global Planet. Change, 71, 13-26, 2010.

Gabrieli, J., Carturan, L., Gabrielli, P., Kehrwald, N., Turetta, C., Cozzi, G., Spolaor, A., Dinale, R., Staffler, H., Seppi, R., dalla Fontana, G., Thompson, L., and Barbante, C.: Impact of Po Valley emissions on the highest glacier of the Eastern European Alps, Atmos. Chem. Phys., 11, 8087-8102, doi:10.5194/acp-118087-2011, 2011.

Gardner, A. S. and Sharp, M. J.: Sensitivity of net mass-balance estimates to near-surface temperature lapse rates when employing the degree-day method to estimate glacier melt, Ann. Glaciol., 50, 80-86, 2009.

Gardner, A. S., Sharp, M. J., Koerner, R. M., Labine, C., Boon, S., Marshall, S. J., Burgess, D. O., and Lewis, D.: Near-surface temperature lapse rates over arctic glaciers and their implications for temperature downscaling, J. Climate, 22, 4281-4298, 2009.

Georges, C. and Kaser, G.: Ventilated and unventilated air temperature measurements for glacier-climate studies on a tropical high mountain site, J. Geophys. Res., 107, 4775, doi:10.1029/2002JD002503, 2002.

Greuell, W. and Böhm, R.: $2 \mathrm{~m}$ temperatures along melting midlatitude glaciers, and implications for the sensitivity of the mass balance to variations in temperature, J. Glaciol., 44, 9-20, 1998.

Greuell, W., Knap, W. H., and Smeets, P. C.: Elevational changes in meteorological variables along a mid-latitude glacier during summer, J. Geophys. Res., 102, 25941-25954, doi:10.1029/97JD02083, 1997.

Haeberli, W., Bosch, H., Scherler, K., Østrem, G. and Wallén, C. (Eds.): World Glacier Inventory: Status 1988, IAHS(ICSI)/UNEP/UNESCO/World Glacier Monitoring Service, Nairobi, 1989.
Haeberli, W., Hoelzle, M., Paul, F., and Zemp, M.: Integrated monitoring of mountain glaciers as key indicators of global climate change: the European Alps, Ann. Glaciol., 46, 150-160, 2007.

Havens, J. M.: Climatological Notes from Axel Heiberg Island, NWT, Canada, Arctic, 17, 261-263, 1964.

Hock, R.: Glacier melt: a review of processes and their modelling, Prog. Phys. Geog., 29, 362-391, 2005.

Huss, M., Bauder, A., and Funk, M.: Homogenization of longterm mass-balance time series, Ann. Glaciol., 50, 198-206, 2009.

Khodakov, V. G.: Glaciers as water resource indicators of the glacial areas of the USSR, IAHS Publ. No. 104, 22-29, 1975.

Klok, E. J. and Oerlemans, J.: Modelled climate sensitivity of the mass balance of Morteratschgletscher and its dependence on albedo parameterization, Int. J. Climatol., 24, 231-245, 2004.

Machguth, H., Purves, R. S., Oerlemans, J., Hoelzle, M., and Paul, F.: Exploring uncertainty in glacier mass balance modelling with Monte Carlo simulation, The Cryosphere, 2, 191204, doi:10.5194/tc-2-191-2008, 2008.

Marshall, S. J., Sharp, M. J., Burgess, D. O., and Anslow, F. S.: Near surface-temperature lapse rates on the Prince of Wales Icefield, Ellesmere Island, Canada: implications for regional downscaling of temperature, Int. J. Climatol., 27, 385-398, 2007.

Michlmayr, G., Lehning, M., Koboltschnig, G., Holzmann, H., Zappa, M., Mott, R., and Schoner, W.: Application of the alpine 3D model for glacier mass balance and glacier runoff studies at Goldbergkees, Austria, Hydrol. Process., 22, 3941-3949, 2008.

Minder, J. R., Mote, P. W., and Lundquist, J. D.: Surface temperature lapse rates over complex terrain: lessons from the Cascade Mountains, J. Geophys. Res., 115, D14122, doi:10.1029/2009JD013493, 2010.

Nash, J. E. and Sutcliffe, J. V.: River flow forecasting through conceptual models. Part 1. A discussion of principles, J. Hydrol., 10, 282-290, 1970.

Nolin, A., Philippe, J., Jefferson, A., and Lewis, S. L.: Present-day and future contributions of glacier runoff to summertime flows in a Pacific Northwest watershed: implications for water resources, Water Resour. Res., 46, W12509, doi:10.1029/2009WR008968, 2010.

Oerlemans, J.: Glaciers and Climate Change, AA Balkema, Lisse, 2001.

Paul, F.: The influence of changes in glacier extent and surface elevation on modeled mass balance, The Cryosphere, 4, 569-581, doi:10.5194/tc-4-569-2010, 2010.

Paul, F., Kääb, A., Maisch, M., Kellenberger, T., and Haeberli, W.: Rapid disintegration of Alpine glaciers observed with satellite data, Geophys. Res. Lett., 31, L21402, doi:10.1029/2004GL020816, 2004.

Paul, F., Machguth, H., and Kääb, A.: On the impact of glacier albedo under conditions of extreme glacier melt: the summer of 2003 in the Alps, EARSeL eProceedings, 4, 139-149, 2005.

Pellicciotti, F., Brock, B., Strasser, U., Burlando, P., Funk, M., and Corripio, J.: An enhanced temperature-index glacier melt model including the shortwave radiation balance: development and testing for Haut Glacier d'Arolla, Switzerland, J. Glaciol., 51, 573587, 2005.

Petersen, L. and Pellicciotti, F.: Spatial and temporal variability of air temperature on a melting glacier: atmospheric controls, extrapolation methods and their effect on melt modeling, 
Juncal Norte Glacier, Chile, J. Geophys. Res., 116, D23109, doi:10.1029/2011JD015842, 2011.

Petersen, L., Pellicciotti, F., Juszak, I., Carenzo, M., and Brock, B.: Suitability of a constant air temperature lapse rate over an Alpine glacier: testing the Greuell and Böhm model as an alternative, Ann. Glaciol., 54, 120-130, 2013.

Raymond, C. F. and Neumann, T. A.: Retreat of Glaciar Tyndall, Patagonia, over the last half-century, J. Glaciol., 51, 239-247, 2005.

Savenije, H. H. G.: Equifinality, a blessing in disguise?, Hydrol. Process., 15, 2835-2838, 2001.

Schytt, V.: Glaciological investigations in the Thule camp area, S.I.P.R.E. Report No. 28, Wilmette, Illinois, USA, 88 pp., 1955.

Shea, J. M. and Moore, R. D.: Prediction of spatially distributed regional-scale fields of air temperature and vapor pressure over mountain glaciers, J. Geophys. Res., 115, D23107, doi:10.1029/2010JD014351, 2010.

Sivapalan, M.: Pattern, process and function: elements of a unified theory of hydrology at the catchment scale, in: Encyclopedia of Hydrological Sciences, Vol. 1, edited by: Anderson, M. G. and McDonnell, J. J., Wiley, Chichester, 193-219, 2006.

Small, E. E.: Hypsometric forcing of stagnant ice margins: pleistocene valley glaciers, San Juan Mountains, Colorado, Geomorphology, 14, 109-121, 1995.
Strasser, U., Corripio, J., Pellicciotti, F., Burlando, P., Brock, B., and Funk, M.: Spatial and temporal variability of meteorological variables at Haut Glacier d'Arolla (Switzerland) during the ablation season 2001: measurements and simulations, J. Geophys. Res., 109, D3103, doi:10.1029/2003JD003973, 2004.

Tarboton, D. G., Bras, R. L., and Rodriguez-Iturbe, I.: On the extraction of channel networks from digital elevation data, Hydrol. Process., 5, 81-100, 1991.

Thibert, E., Blanc, R., Vincent, C., and Eckert, N.: Glaciological and volumetric mass-balance measurements: error analysis over 51 years for Glacier de Sarennes, French Alps, J. Glaciol., 54, 522-532, 2008.

van den Broeke, M. R.: Momentum, heat, and moisture budgets of the katabatic wind layer over a midlatitude glacier in summer, J. Appl. Meteorol., 36, 763-774, 1997.

WMO (World Meteorology Organization): Intercomparison of models for snowmelt runoff, Operational Hydrology Report 23 (WMO no. 646), Geneva, Switzerland, 1986.

Zanon, G.: Recent glaciological research in the Ortles-Cevedale region (Italian Alps), GFDQ - Geografia Fisica e Dinamica Quaternaria, 5, 75-81, 1982.

Zemp, M., Paul, F., Hoelzle, M., and Haeberli, W.: Glacier fluctuations in the European Alps 1850-2000: an overview and spatio-temporal analysis of available data, in: The Darkening Peaks: Glacial Retreat in Scientific and Social Context, edited by: Orlove, B., Wiegandt, E., and Luckman B., University of California Press, Berkeley, 152-167, 2008. 